University of Nebraska - Lincoln

DigitalCommons@University of Nebraska - Lincoln

USGS Staff -- Published Research

US Geological Survey

2016

\title{
Component greenhouse gas fluxes and radiative balance from two deltaic marshes in Louisiana: Pairing chamber techniques and eddy covariance
}

Ken W. Krauss

U.S. Geological Survey, kraussk@usgs.gov

Guerry O. Holm Jr.

Brian C. Perez

David E. McWhorter

Nicole Cormier

U.S. Geological Survey

See next page for additional authors

Follow this and additional works at: http://digitalcommons.unl.edu/usgsstaffpub

Part of the Geology Commons, Oceanography and Atmospheric Sciences and Meteorology Commons, Other Earth Sciences Commons, and the Other Environmental Sciences Commons

Krauss, Ken W.; Holm, Guerry O. Jr.; Perez, Brian C.; McWhorter, David E.; Cormier, Nicole; Moss, Rebecca F.; Johnson, Darren J.; Neubauer, Scott C.; and Raynie, Richard C., "Component greenhouse gas fluxes and radiative balance from two deltaic marshes in Louisiana: Pairing chamber techniques and eddy covariance" (2016). USGS Staff -- Published Research. 982.

http://digitalcommons.unl.edu/usgsstaffpub/982

This Article is brought to you for free and open access by the US Geological Survey at DigitalCommons@University of Nebraska - Lincoln. It has been accepted for inclusion in USGS Staff -- Published Research by an authorized administrator of DigitalCommons@University of Nebraska - Lincoln. 
Authors

Ken W. Krauss, Guerry O. Holm Jr., Brian C. Perez, David E. McWhorter, Nicole Cormier, Rebecca F. Moss, Darren J. Johnson, Scott C. Neubauer, and Richard C. Raynie 


\section{Journal of Geophysical Research: Biogeosciences}

\section{RESEARCH ARTICLE \\ 10.1002/2015JG003224 \\ Key Points: \\ - A brackish marsh was a source and a \\ Component greenhouse gas fluxes and radiative balance from two deltaic marshes in Louisiana: Pairing chamber techniques and eddy covariance} freshwater marsh was a sink for net ecosystem fluxes of $\mathrm{C}$

- $\mathrm{CH}_{4}$ and $\mathrm{CO}_{2}$ emission estimates were different using eddy covariance versus static flux chambers

- Radiative balance of marshes varied by accounting technique applied

Correspondence to:

K. W. Krauss,

kraussk@usgs.gov

\section{Citation:}

Krauss, K. W., G. O. Holm Jr, B. C. Perez, D. E. McWhorter, N. Cormier, R. F. Moss, D. J. Johnson, S. C. Neubauer, and R. C. Raynie (2016), Component greenhouse gas fluxes and radiative balance from two deltaic marshes in Louisiana: Pairing chamber techniques and eddy covariance, J. Geophys. Res. Biogeosci., 121, 1503-1521, doi:10.1002/ 2015JG003224.

Received 25 SEP 2015 Accepted 19 MAY 2016 Accepted article online 23 MAY 2016 Published online 14 JUN 2016

This document is a U.S. government work and is not subject to copyright in the United States.

@2016. American Geophysical Union. All Rights Reserved.

\author{
Ken W. Krauss ${ }^{1}$, Guerry O. Holm Jr${ }^{2}$, Brian C. Perez ${ }^{2}$, David E. McWhorter ${ }^{2}$, Nicole Cormier ${ }^{1}$, \\ Rebecca F. Moss ${ }^{3}$, Darren J. Johnson ${ }^{3}$, Scott C. Neubauer ${ }^{4}$, and Richard C. Raynie ${ }^{5}$ \\ ${ }^{1}$ Wetland and Aquatic Research Center, U.S. Geological Survey, Lafayette, Louisiana, USA, ${ }^{2} \mathrm{CH} 2 \mathrm{M}$, Baton Rouge, Louisiana, \\ USA, ${ }^{3}$ Cherokee Nation Technologies, USGS Wetland and Aquatic Research Center, Lafayette, Louisiana, USA, ${ }^{4}$ Department \\ of Biology, Virginia Commonwealth University, Richmond, Virginia, USA, ${ }^{5}$ Louisiana Coastal Protection and Restoration \\ Authority, Baton Rouge, Louisiana, USA
}

Abstract Coastal marshes take up atmospheric $\mathrm{CO}_{2}$ while emitting $\mathrm{CO}_{2}, \mathrm{CH}_{4}$, and $\mathrm{N}_{2} \mathrm{O}$. This ability to sequester carbon $(C)$ is much greater for wetlands on a per area basis than from most ecosystems, facilitating scientific, political, and economic interest in their value as greenhouse gas sinks. However, the greenhouse gas balance of Gulf of Mexico wetlands is particularly understudied. We describe the net ecosystem exchange ( $\mathrm{NEE}_{\mathrm{c}}$ ) of $\mathrm{CO}_{2}$ and $\mathrm{CH}_{4}$ using eddy covariance $(\mathrm{EC})$ in comparison with fluxes of $\mathrm{CO}_{2}$, $\mathrm{CH}_{4}$, and $\mathrm{N}_{2} \mathrm{O}$ using chambers from brackish and freshwater marshes in Louisiana, USA. From EC, we found that $182 \mathrm{~g} \mathrm{C} \mathrm{m}^{-2} \mathrm{yr}^{-1}$ was lost through $\mathrm{NEE}_{\mathrm{c}}$ from the brackish marsh. Of this, $11 \mathrm{~g} \mathrm{C} \mathrm{m}^{-2} \mathrm{yr}^{-1}$ resulted from net $\mathrm{CH}_{4}$ emissions and the remaining $171 \mathrm{~g} \mathrm{Cm}^{-2} \mathrm{yr}^{-1}$ resulted from net $\mathrm{CO}_{2}$ emissions. In contrast, $-290 \mathrm{~g} \mathrm{C} \mathrm{m}^{2} \mathrm{yr}^{-1}$ was taken up through $\mathrm{NEE}_{\mathrm{c}}$ by the freshwater marsh, with $47 \mathrm{~g} \mathrm{C} \mathrm{m}^{-2} \mathrm{yr}^{-1}$ emitted as $\mathrm{CH}_{4}$ and $-337 \mathrm{~g} \mathrm{Cm}^{-2} \mathrm{yr}^{-1}$ taken up as $\mathrm{CO}_{2}$. From chambers, we discovered that neither site had large fluxes of $\mathrm{N}_{2} \mathrm{O}$. Sustained-flux greenhouse gas accounting metrics indicated that both marshes had a positive (warming) radiative balance, with the brackish marsh having a substantially greater warming effect than the freshwater marsh. That net respiratory emissions of $\mathrm{CO}_{2}$ and $\mathrm{CH}_{4}$ as estimated through chamber techniques were 2-4 times different from emissions estimated through $\mathrm{EC}$ requires additional understanding of the artifacts created by different spatial and temporal sampling footprints between techniques.

\section{Introduction}

$\mathrm{CO}_{2}$ is currently building in the atmosphere at a rate of approximately $1.9 \mathrm{ppm} \mathrm{yr}^{-1}$, representing roughly $45 \%$ (4 of $8.6 \mathrm{Pg} \mathrm{Cyr}^{-1}$ ) [Ciais et al., 2013] of the $\mathrm{CO}_{2}$ being emitted from anthropogenic activities such as fossil fuel combustion, cement production, and land use change [Ciais et al., 2013]. $\mathrm{CO}_{2}$ is responsible for the majority of the current global warming trend [Archer, 2010], and overall, approximately $68 \mathrm{Pg} \mathrm{Cyr}^{-1}$ results from global soil $\mathrm{CO}_{2}$ emissions [Raich and Schlesinger, 1992]. Similarly, $\mathrm{CH}_{4}$ concentrations have risen at roughly $0.013 \mathrm{PgC} \mathrm{yr}^{-1}$ [Ciais et al., 2013], with this increase accounting for approximately $25 \%$ of the current global warming trend [Archer, 2010], due in large part to the high radiative efficiency of $\mathrm{CH}_{4}$.

A discussion of wetland processes has long been germane to climate issues because wetlands emit $20-25 \%$ of $\mathrm{CH}_{4}$ globally to the atmosphere [Whalen, 2005], but wetlands are also particularly efficient $\mathrm{CO}_{2}$ sinks. Peatlands alone store approximately $16-33 \%$ of the terrestrial soil carbon pool yet occupy only about $3 \%$ of the Earth's surface [Gorham, 1991; Bridgham et al., 2006]. However, the climatic influence of a particular wetland (i.e., does a site have a net warming or cooling effect?) depends on the rate and direction of greenhouse gas fluxes as well as the time frame of interest. The radiative balance of a site may be positive (i.e., net warming) over a defined time period, but wetlands that sequester $C$ will eventually become net radiative sinks, with that time frame ranging from decades to thousands of years depending on the ratio of net $\mathrm{CO}_{2}$ uptake to emissions of $\mathrm{CH}_{4}$ and $\mathrm{N}_{2} \mathrm{O}$ [Frolking et al., 2006; Neubauer, 2014]. Greenhouse gas fluxes and climatic influences for specific wetlands could change rapidly with shifts in the oxidation of soil $\mathrm{C}$ stores, acute emissions from storms or human activity, increased microbial respiration, and increased root respiration [Hanson et al., 2000]. Furthermore, ecosystem respiration (from both $\mathrm{CO}_{2}$ and $\mathrm{CH}_{4}$ ) often intensifies as atmospheric $\mathrm{CO}_{2}$ concentrations rise [Megonigal and Schlesinger, 1997; Schlesinger and Andrews, 2000]. 
How we assess $C$ sequestration relative to the climatic influence of wetland ecosystems is critical. Many techniques developed for measuring greenhouse gas emissions are more useful in upland systems, where $\mathrm{CO}_{2}$ flux from soil and organic matter provides a major component of the radiative $\mathrm{C}$ flux [Raich and Schlesinger, 1992]. Even in upland systems, rates of greenhouse gas fluxes vary widely among location and among the technique used [e.g., Edwards and Sollins, 1973; Cropper et al., 1985; Raich et al., 1990; Knoepp and Vose, 2002; Rochette et al., 1992, 1997]; variability in the assessment of greenhouse gas flux is indeed inherent to the process. Accurately assessing spatial variation in greenhouse gas emissions is particularly problematic in wetlands, where diverse biogeochemical conditions (i.e., anoxic to suboxic soils) and hydrological regimes (i.e., seasonally, permanently, and tidally flooded) produce not only $\mathrm{CO}_{2}$ emissions but also $\mathrm{CH}_{4}$ emissions in appreciable quantities. The majority of wetland greenhouse gas studies also use single techniques, which limit assessments to a specific scale.

However, comparisons of greenhouse gas fluxes at different spatial scales, e.g., hundreds of square meters or greater with eddy covariance methods versus $\sim 1 \mathrm{~m}^{2}$ with chambers [Christensen et al., 1996; Norman et al., 1997; Teh et al., 2011; Budishchev et al., 2014], are particularly valuable, can provide insight into which components of the ecosystem might be contributing to specific gas emissions, may differ considerably, and are scarce in wetlands [Meijide et al., 2011]. For example, $\mathrm{CH}_{4}$ emissions are often routed through vegetation [Garnet et al., 2005; Pangala et al., 2013], a process discernable only at small spatial scales. Yet the cumulative balance of $\mathrm{CO}_{2}: \mathrm{CH}_{4}$ exchange across an entire wetland (per hectare) and net ecosystem exchange of carbon $\left(\mathrm{NEE}_{\mathrm{c}}\right)$ are best determined through larger scale approaches, such as eddy covariance. We often use chambers to represent components of $\mathrm{NEE}_{\mathrm{c}}$ across large spatial scales. Although other studies have assessed $\mathrm{NEE}_{\mathrm{c}}$ of $\mathrm{CO}_{2}$ in natural tidal, restored, and agricultural wetlands through eddy covariance techniques [Kathilankal et al., 2008; Rocha and Goulden, 2009; Moffett et al., 2010; Hatala et al., 2012; Schäfer et al., 2014; Artigas et al., 2015; Anderson et al., 2016], there are limited studies from the northern Gulf Coast region that can be drawn upon to understand $C$ sequestration of coastal wetlands versus the influence that those wetlands might have on the climate by releasing greenhouse gases. The existing greenhouse gas flux data for the northern Gulf Coast region are from chamber studies, and it is uncertain whether these studies are representative of broad-area fluxes from brackish and freshwater marshes.

In this study, we measured $\mathrm{NEE}_{\mathrm{c}}$ of $\mathrm{CO}_{2}$ and $\mathrm{CH}_{4}$ using eddy covariance (hereafter, eddy covariance (EC)) techniques for two marsh types in coastal Louisiana. Simultaneously, we measured and modeled rates of respiratory $\mathrm{CO}_{2}, \mathrm{CH}_{4}$, and $\mathrm{N}_{2} \mathrm{O}$ fluxes through small chambers. We wanted to explore three questions relative to brackish and freshwater marshes. First, how do rates and patterns of $\mathrm{NEE}_{\mathrm{c}}$ and soil/vegetation respiratory fluxes of $\mathrm{C}$ and $\mathrm{N}_{2} \mathrm{O}$ differ seasonally to influence carbon dynamics for each marsh? Second, how do estimates of $\mathrm{CH}_{4}$ and $\mathrm{CO}_{2}$ emissions differ between $\mathrm{EC}$ and chamber techniques? Third, how do these marshes contribute to radiative forcing through suppressing or enhancing greenhouse gas emissions when assessed over broad spatial scales?

\section{Methods}

\subsection{Study Sites}

This study focuses on two marsh sites in coastal Louisiana (Figure 1). Both sites were selected with three primary criteria in mind. First, both sites needed to be representative of similar marsh types in Louisiana. The coastal zone of Louisiana has approximately $2144 \mathrm{~km}^{2}$ of brackish marsh and approximately $2837 \mathrm{~km}^{2}$ of freshwater marsh [Enwright et al., 2015], and both sites have vegetation assemblages and hydrological signatures consistent with these wetland types. Many brackish marshes in Louisiana dominated by Spartina patens (Aiton) Muhl. are undergoing stress and peat collapse from persistent submergence and saltwater intrusion [DeLaune et al., 1994], and our brackish marsh is representative of such deterioration. Second, marsh coverage needed to be fairly continuous within a circular radius of approximately $200 \mathrm{~m}$ ( $12.5 \mathrm{ha}$ ) to attempt EC measurements and avoid open water. Third, sites needed to be accessible both in the physical and legal sense.

The first site (hereafter referred to as "brackish marsh") is adjacent to Pointe-aux-Chenes Wildlife Management Area (WMA), approximately $24 \mathrm{~km}$ southeast of Houma $\left(29^{\circ} 30^{\prime} 04.77^{\prime \prime} \mathrm{N} ; 90^{\circ} 26^{\prime} 41.65^{\prime \prime} \mathrm{W}\right.$; Coastwide Reference Monitoring System (CRMS-Wetlands) site 2825). Soils are organic (40-70\% organic content) with low bulk density 


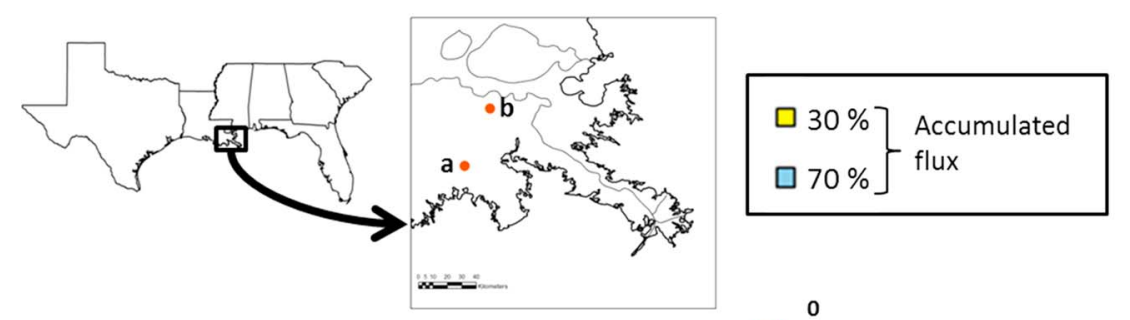

a
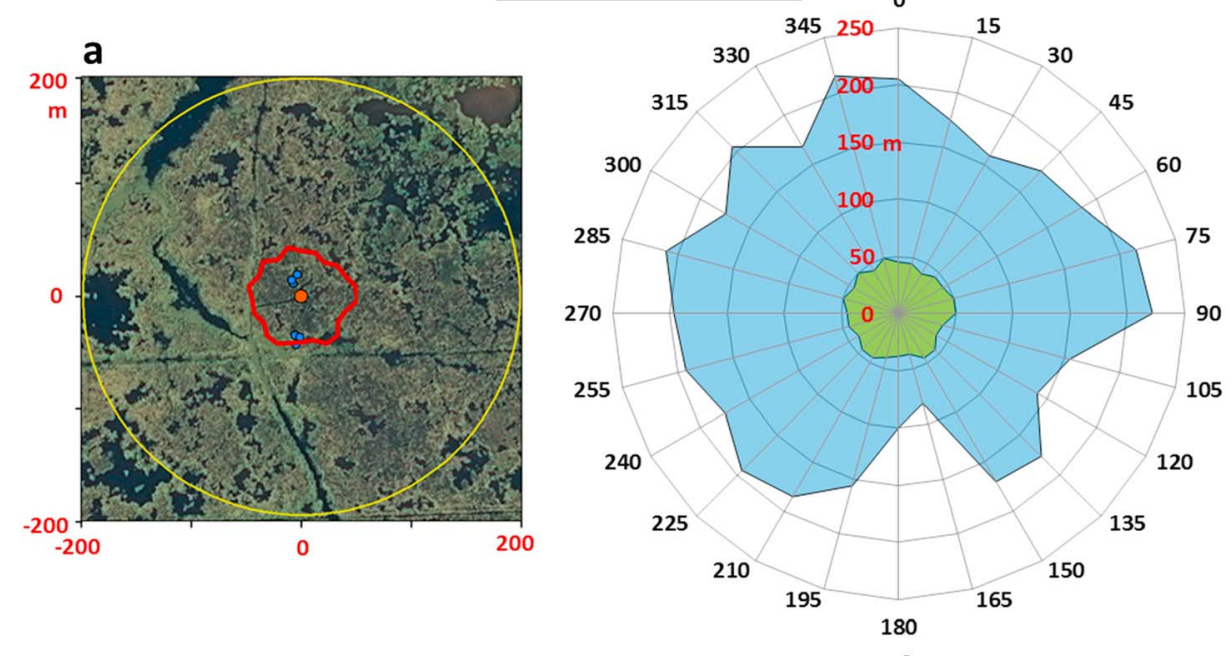

b
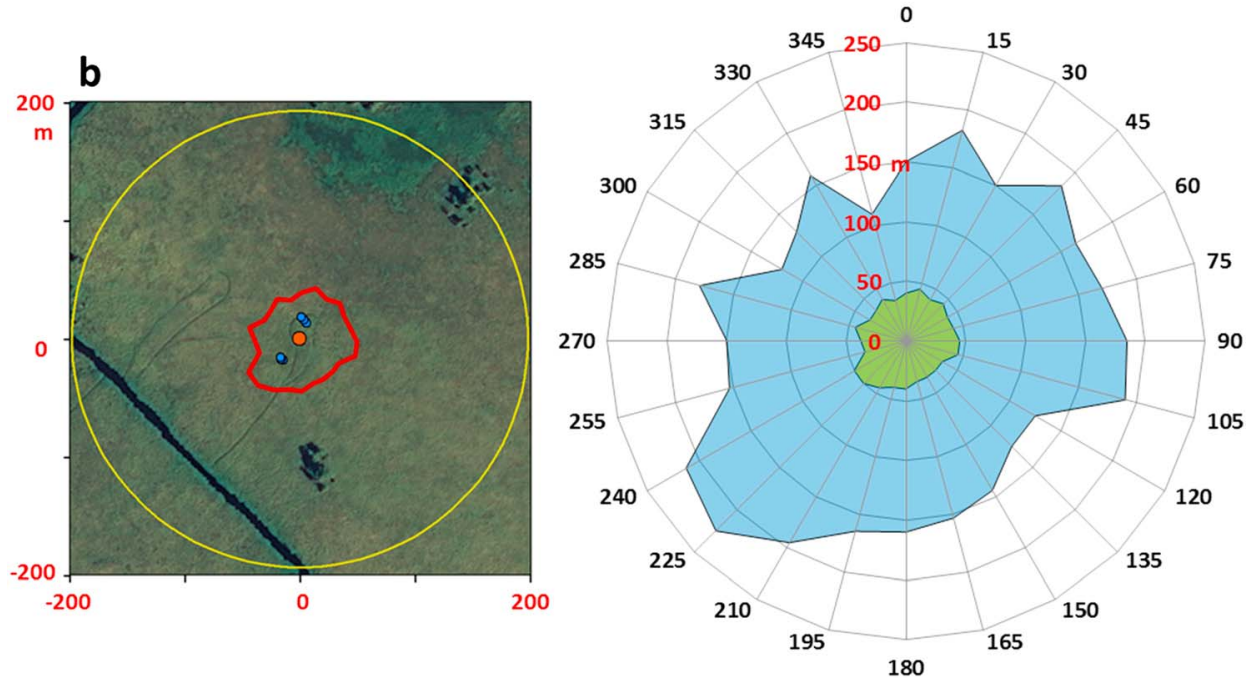

Figure 1. (a) Location of the brackish marsh study site adjacent to Pointe-aux-Chenes Wildlife Management Area (WMA) and (b) location of the freshwater marsh study site at Salvador WMA, Louisiana, USA. (left column) Aerial images depict actual marsh distribution within a 12.5 ha area (yellow circle), the location of the EC tower (orange dot), region corresponding to $30 \%$ accumulated fluxes of $\mathrm{CO}_{2}$ and $\mathrm{CH}_{4}$ (red polygon), and the location of static flux chambers (blue dots) within the EC footprint. For the (right column) footprint diagram, yellow shading and blue shading correspond to $30 \%$ and $70 \%$, respectively, of accumulated $\mathrm{NEE}_{\mathrm{C}}$ calculated over the duration of EC measurements.

$\left(<0.2 \mathrm{~g} \mathrm{~cm}^{-3}\right)$ and have a live rooting depth $\leq 30 \mathrm{~cm}$ (G. Holm, unpublished data, 2012). The site is characterized as mesohaline (salinity of $9.15 \pm 1.5 \mathrm{SE}$ practical salinity unit (psu) during the period of study). Our study was conducted in a fairly intact marsh area dominated by S. patens; small areas of open water between vegetation patches are common for P. patens marshes in Louisiana (see Figure 1a).

The second site (hereafter referred to as "freshwater marsh") is on Salvador WMA, which is approximately $19 \mathrm{~km}$ southeast of New Orleans (29 $51^{\prime} 31.29^{\prime \prime} \mathrm{N} ; 90^{\circ} 17^{\prime} 12.80^{\prime \prime}$; CRMS-Wetlands site 3166). The freshwater marsh (salinity of $0.23 \pm 0.1 \mathrm{SE}$ psu during the period of study) is typical of freshwater deltaic plain wetlands [Swarzenski et al., 1991; Sasser et al., 1996] which have semibuoyant mats capable of adjusting to moderate changes in water level. 


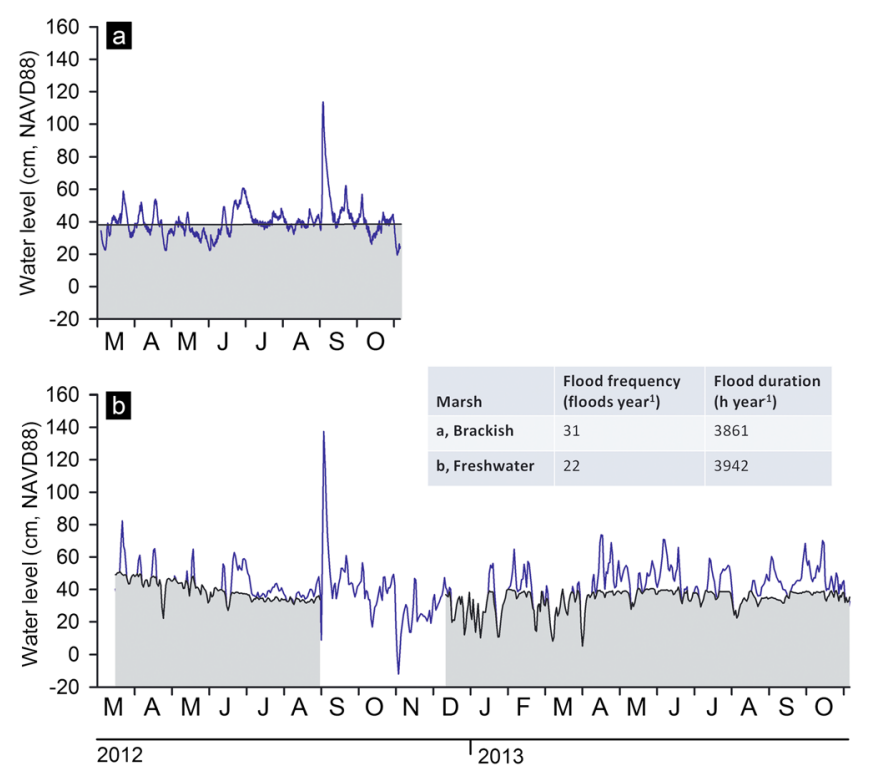

Figure 2. Hydrologic characteristics of the (a) brackish marsh and (b) freshwater marsh for periods where hydrology data overlap with EC and chamber measurements, including hydroperiod summaries (flood frequency and duration). Shaded areas represent water levels below the soil surface, depicting a static surface for the brackish marsh and a dynamic surface for the semibuoyant freshwater marsh, both to approximately NAVD 88. The interval where shading is omitted from the freshwater marsh corresponds to missing vertical motion data for the floating mat (G. Holm, unpublished data, 2012).
The dominant species are Sagittaria lancifolia and Leersia oryzoides, with patchy areas of Typha domingensis. The soils are $>75 \%$ organic matter with a bulk density of $<0.10 \mathrm{~g} \mathrm{~cm}^{-3}$, live rooting depth of up to $60 \mathrm{~cm}(\mathrm{G}$. Holm, unpublished data, 2012), and basal peats as deep as 2-4 m [Kosters et al., 1987]. This site is also within the receiving basin of a freshwater diversion (Davis Pond) from the Mississippi River, which is designed to reintroduce seasonal pulses of fresh water, nutrients, and sediments from the river to the Barataria estuary. Our study was conducted in a healthy freshwater marsh with near-continuous vegetation coverage (see Figure 1b).

Both sites are microtidal (ran$\mathrm{ge}<30 \mathrm{~cm}$ ) with major wind events influencing duration of flooding (Figure 2). Mean annual temperature for coastal Louisiana (Houma) is $20.8^{\circ} \mathrm{C}$, with annual means ranging from 15.6 to $26.0^{\circ} \mathrm{C}$, and a mean annual rainfall of $1580 \mathrm{~mm}$ [U.S. Climate Data, 2016].

\subsection{Static Flux Measurements}

We used static flux chambers (in the sense of Livingston and Hutchinson [1995]) (hereafter referred to as "chambers") to measure respiratory fluxes of greenhouse gases $\left(\mathrm{CO}_{2}, \mathrm{CH}_{4}\right.$, and/or $\left.\mathrm{N}_{2} \mathrm{O}\right)$ from the soil and through vegetation within $40 \mathrm{~m}$ of EC systems operating on the same sites (Figure 1). Two elevated boardwalks were constructed approximately $0.7 \mathrm{~m}$ above the marsh surface at each site to prevent investigator disturbance during sampling. A set of three chambers was installed along the two separate boardwalks, for a total of six chambers per site split between two replicate areas ( $n=3$ per replicate; $n=2$ replicates). Chambers were placed as far from the boardwalk as possible. The square chambers $(29.4 \times 29.4 \mathrm{~cm}$ or $864 \mathrm{~cm}^{2}$ ) were made of white plastic material to reflect sunlight and limit heating during sampling, and inserted $5 \mathrm{~cm}$ into the soil by cutting through the marsh and sealing edges by pressing cut soils. Chambers were installed and left to settle for 1 month before the first set of measurements were made and left in place between 9 (brackish marsh) and 21 months (freshwater marsh) for a total of 5 and 11 sampling periods, respectively. The chambers were $30.5 \mathrm{~cm}$ tall and remained opened when measurements were not underway. Each chamber had small ports $(0.64 \mathrm{~cm})$ on each of the four sides just at the soil surface to allow for natural water exchange during tidal cycles when chambers were not being sampled. The holes were plugged with Nalgene stoppers during sampling.

During sampling, portable $27 \mathrm{~cm}$ tall tops were placed on the chambers, increasing sample chamber height to approximately $57 \mathrm{~cm}$ above the soil. Chamber tops simulate dark conditions allowing little to no light into the chamber. All chambers included existing vegetation on sites; while no vegetation was removed, at times larger plants had to be bent slightly, folded, or cut (infrequently). The top of each chamber base was outfitted with a trough that held water during sampling. Chamber tops were inserted into the water trough to prevent significant egress of gases and were not otherwise vented. Chamber tops were fitted with two brass, $0.9 \mathrm{~cm}$ inlets with rubber septa from which gases were collected with a needle and syringe and injected into $5 \mathrm{~mL}$ vacuum-evacuated vials. Tygon tubing was attached to each septum and suspended into the chamber at $15 \mathrm{~cm}$ below the chamber top. The volume of air in the head space (including tubing) of each chamber was mixed manually by sucking air into a $30 \mathrm{~mL}$ syringe and forcefully injecting that air back into the chamber 
at the tubing depth of $15 \mathrm{~cm}$ at least 3 times prior to each gas extraction to ensure a well-mixed chamber volume. Initial samples were collected seconds before tops were emplaced by lowering the syringe directly to the center of the open chamber approximately $5-10 \mathrm{~cm}$ above ground and at intervals of 30 and $60 \mathrm{~min}$ thereafter from the chamber inlets. All samples were taken during daylight hours between 1000 and 1600 . Samples were transported back to the U.S. Geological Survey (USGS) Wetland and Aquatic Research Center in Lafayette, Louisiana, and analyzed within $24 \mathrm{~h}$ for $\mathrm{CO}_{2}, \mathrm{CH}_{4}$, and $\mathrm{N}_{2} \mathrm{O}$ with a multicolumn gas chromatograph (model CP-3800, Varian, Inc., Palo Alto, CA, USA) calibrated using certified standards (Scott Specialty Gases, Inc., Plumsteadville, PA, USA). Rates of flux were determined from the linear portion of fit saturation curves contrasting time with volume-adjusted gas concentrations.

\subsection{EC Data Collection and Processing}

We used EC techniques to determine $\mathrm{NEE}_{\mathrm{c}}$ in the form of $\mathrm{CO}_{2}$ and $\mathrm{CH}_{4}$ above the wetland surface. Elevated tripods comprising a Li-Cor closed path $\mathrm{CO}_{2} / \mathrm{H}_{2} \mathrm{O}$ sensor (LI-7200), Li-Cor open path $\mathrm{CH}_{4}$ sensor (LI-7700, Li-Cor Biosciences, Nebraska, USA), and a sonic anemometer (Gill Windmaster Pro, Gill Instruments Ltd, Lymington, England) were installed on both sites. The EC systems were located on $3 \times 3 \mathrm{~m}$ platforms elevated $1.0 \mathrm{~m}$ above the soil surface within uniform wetland areas of similar roughness and a $200 \mathrm{~m}$ fetch where wind directions could be accessed in all directions to maximize data capture (Figure 1). Both sites had herbaceous canopy heights of 0.5 to $1.2 \mathrm{~m}$. EC data were collected from $3.4 \mathrm{~m}$ and $3.6 \mathrm{~m}$ above the soil for the brackish and freshwater marsh sites, respectively; EC system heights were chosen to limit the flux footprint to $\leq 200 \mathrm{~m}$ (70\% of the footprint contribution) (Figure 1). EC sensor height was selected with a footprint estimator using the following assumptions: the standard deviation of vertical velocity fluctuations was $0.3 \mathrm{~m} \mathrm{~s}^{-1}$; surface friction velocity was $0.3 \mathrm{~m} \mathrm{~s}^{-1}$; planetary boundary layer height was $1000 \mathrm{~m}$; and roughness length was $0.1 \mathrm{~m}$ [Kljun et al., 2004].

For EC systems, we report data from 8 October 2011 to 5 December 2012 for the brackish marsh and 15 December 2011 to 18 November 2013 for the freshwater marsh. Raw data were collected at $10 \mathrm{~Hz}$ frequency, binned in 30 min data files and downloaded monthly when serviced. All instruments $\left(\mathrm{CO}_{2} / \mathrm{H}_{2} \mathrm{O}\right.$ sensor, $\mathrm{CH}_{4}$ sensor, and sonic anemometer) were factory calibrated prior to initial deployment and cleaned at 4-6 week intervals. Given the remote nature of the sites, gas quantities needed for the calibration shroud, and adequate environmental stability in the field, the $\mathrm{CH}_{4}$ sensors were retrieved after 6 months and checked for zero and span in the laboratory using zero grade and $10 \mathrm{ppm} \mathrm{CH}_{4}$ primary standard gases (MESA Specialty Gases and Equipment, Santa Ana, CA, USA). The $\mathrm{CO}_{2}$ sensors were checked approximately every 8 weeks in the field with zero certified standard gas and then checked/calibrated for zero and span in the laboratory with zero grade and 500 ppm $\mathrm{CO}_{2}$ primary standard gases, after 6 months in the field. After 8 weeks, drift due to contamination was biased on the order of $\leq 35 \mathrm{ppm} \mathrm{CO}_{2}$. The freshwater site $\mathrm{CO}_{2}$ sensor malfunctioned and was replaced with a new factory calibrated sensor, resulting in a data gap from 25 July to 9 August 2012. Sensors at both sites were removed from the field prior to Hurricane Isaac resulting in a data gap from 26 August to 5 September 2012. Other intermittent gaps in data for $\mathrm{CH}_{4}$ and $\mathrm{CO}_{2}$ were due to data removal when instruments malfunctioned, lost power, were contaminated, or were subjected to poor atmospheric conditions (see below).

Fluxes of $\mathrm{CO}_{2}$ and $\mathrm{CH}_{4}$ were determined by incorporating mean air density, mean covariance of instantaneous deviations of vertical wind velocity, and the mixing ratio of $\mathrm{CO}_{2}$ or $\mathrm{CH}_{4}$ in the air:

$$
f_{\mathrm{CO} 2 / \mathrm{CH} 4}=\left(\overline{p a} \overline{w^{\prime} s^{\prime}}\right)
$$

where

$f_{\mathrm{CO} 2 / \mathrm{CH} 4}=\mathrm{CO}_{2}$ or $\mathrm{CH}_{4}$ flux $\left(\mu \mathrm{mol} \mathrm{m}{ }^{-2} \mathrm{~s}^{-1}\right)$;

$\overline{p a}=$ mean air density $\left(\mu \mathrm{mol}\right.$ air $\left.\mathrm{m}^{-3}\right)$;

$\overline{W^{\prime} s^{\prime}}=$ mean covariance of instantaneous vertical wind velocity and mixing ratio of $\mathrm{CO}_{2}$ or $\mathrm{CH}_{4}$ in air;

$W^{\prime}=$ instantaneous vertical wind velocity $\left(\mathrm{m} \mathrm{s}^{-1}\right)$;

$s^{\prime}=$ instantaneous mixing ratio of $\mathrm{CO}_{2}$ or $\mathrm{CH}_{4}$ in air ( $\mu \mathrm{mol}$ gas $\left.(\mu \mathrm{mol} \text { air })^{-1}\right)$.

We used open source, Eddy Pro 4.0 software [Li-Cor Biosciences, 2012], to process data from EC systems. Data were preconditioned and corrected, and quality control tests were run according to the processing options 
Table 1. Methods Used for Conditioning and Correcting $30 \mathrm{~min}$ Eddy Covariance Flux Measurements in Eddy Pro Software for Determining $\mathrm{CH}_{4}$ and $\mathrm{CO}_{2}$ Fluxes From Brackish and Freshwater Marshes in Louisiana, USA

Data Conditioning, Corrections, and Quality Control

Selection/Method

Compensation for air density fluctuations

Correction for frequency response

Axis rotation for sonic anemometer tilt correction

Detrending of raw time series

Time lag compensation between wind and gas terms

Statistical control tests for fluxes

Quality control tests for fluxes

Flux footprint estimation
Webb et al. [1980] and Ibrom et al. [2007]

Moncrieff et al. [1997, 2004]

Double rotation

Block averaging

Time lag optimization and maximum covariance Vickers and Mahrt [1997]

Foken et al. [2004] and Göckede et al. [2008]

Kljun et al. [2004] and Kormann and Meixner [2001]

defined in Table 1 [see also Holm et al., 2016]. Data were subjected to two quality control tests for steady state and turbulence (based on Foken and Wichura [1996], Foken et al. [2004], and Mauder and Foken [2006]), which determines if the assumptions of the EC method are not strongly violated for a particular half hour. Thus, under this scheme, we retained only data that were flagged " 0 " (excellent) and "1" (suitable for general budget estimation), while poor quality data not satisfying these assumptions were discarded. The processed 30 min data resulted in mean $\mathrm{CO}_{2}$ and $\mathrm{CH}_{4}$ fluxes, which were filtered further, to eliminate potentially spurious values based on the following thresholds: $\mathrm{CH}_{4}<-0.1$ and $>0.5 \mu \mathrm{mol} \mathrm{m}^{-2} \mathrm{~s}^{-1} ; \mathrm{CO}_{2}<-25$ and $>20 \mu \mathrm{mol} \mathrm{m} \mathrm{s}^{-2}$; sensible heat $<-100$ and $>500 \mathrm{~W} \mathrm{~m}^{-2}$; and latent heat $<-100$ and $>600 \mathrm{~W} \mathrm{~m}^{-2}$. Halfhourly fluxes were also removed during periods of heavy precipitation, sensor contamination $(<15 \%$ signal strength for $\mathrm{CH}_{4}$ and automatic gain control $>70 \% \mathrm{CO}_{2} / \mathrm{H}_{2} \mathrm{O}$ ), and extreme friction velocity events $\left(0.05>u^{*}>1.5 \mathrm{~m} \mathrm{~s}^{-1}\right)$. Most of the data that were retained for analysis (i.e., $\left.>80 \%\right)$ had a friction velocity $>0.1 \mathrm{~m} \mathrm{~s}^{-1}$. Other studies, with level terrain and short canopy (e.g., prairie, pasture, and grassland) similar to our study, have demonstrated that flux data were considered reliable also during relatively low friction velocity $\left(u^{*}<0.1 \mathrm{~m} \mathrm{~s}^{-1}\right.$ ) compared to other sites (e.g., forested and tall canopy) [Gu et al., 2005; Papale et al., 2006; Meijide et al., 2011; Wolf et al., 2011; Galvagno et al., 2013].

To develop daily integrated $\mathrm{CO}_{2}$ estimates, missing 30 min data were gap filled with an algorithm [Reichstein et al., 2005], which used the covariance of meteorological variables and the covariance of fluxes to provide an estimate of $\mathrm{CO}_{2}$ flux based on similar meteorological conditions for those $30 \mathrm{~min}$ periods. All algorithm calculations based on Reichstein et al. [2005] were processed using the eddy covariance gap-filling and fluxpartitioning tool (Max Planck Institute for Biogeochemistry, http://www.bgc-jena.mpg.de/ MDlwork/eddyproc/, accessed 4 April 2016). The algorithm provided estimates of ecosystem respiration $\left(R_{\text {eco }}\right)$ and gross ecosystem production (GEP) based on the short-term temperature sensitivity of respiration in order to extrapolate respiration from nighttime to daytime periods. We selected air temperature from the EC tower $\left(T_{\mathrm{a}-\mathrm{tower}}\right)$ as the input for flux partitioning instead of water/soil temperature given the more complete data stream of $T_{\mathrm{a} \text {-tower. }}$.

The gap-filled data were assigned a Quality of A, B, or C (high, medium, and low, respectively) based on availability of meteorological data and the time window of extrapolation. Further description of the fluxpartitioning and gap-filling method is described by Reichstein et al. [2005]. For the brackish marsh there were a total of 20,399 half-hourly $\mathrm{CO}_{2}$ measurements, of which 10,931 were gap filled, resulting in $53.6 \%$ rejected. Of these gap-filled data, 64\%, 16\%, and 20\% were categorized as Filling Quality A, B, and C, respectively. For the $\mathrm{CO}_{2}$ data from the freshwater marsh, there were a total of 35,328 half-hourly measurements, of which 16,986 fluxes were gap filled, resulting in $48.1 \%$ rejected. Of these gap-filled data, $65 \%, 20 \%$, and $15 \%$ were categorized as Filling Quality $\mathrm{A}, \mathrm{B}$, and $\mathrm{C}$, respectively. We rejected $10-18 \%$ more $\mathrm{CO}_{2}$ and $\mathrm{CH}_{4}$ half-hourly measurements at night than during the day for the brackish marsh and 21-23\% more measurements at night than during the day for the freshwater marsh.

Uncertainties were estimated for gap-filled data based on average standard deviations by simulating gaps and applying gap-filling procedures in comparison to actual data retained using online algorithms. Uncertainty for $\mathrm{NEE}_{\mathrm{c}}$ is provided for each $30 \mathrm{~min}$ interval, and overall annual model uncertainty for actual versus gap-filled data was calculated using a derivation of Shoemaker et al. [2015], assuming random uncertainty is part of the $\mathbf{3 0}$ min uncertainty term provided by the eddy covariance gap-filling and flux-partitioning tool:

$$
U=\sqrt{\sum_{t=0}^{\text {year }}\left(\mathrm{SE}^{2}\right)} \text {. }
$$


where $U$ is annual uncertainty in $\mathrm{NEE}_{\mathrm{c}}\left(\mathrm{gC} \mathrm{m}^{2} \mathrm{yr}^{-1}\right)$ and $\mathrm{SE}\left(\mathrm{gC} \mathrm{m}^{2} \mathrm{~d}^{-1}\right)$ is the average of 30 min uncertainty values (error) scaled to daily values. For the brackish marsh, maximum $U$ was $67.9 \mathrm{~g} \mathrm{CO}_{2}-\mathrm{C} \mathrm{m}^{2} \mathrm{yr}^{-1}$ for 2011 and 2012, ranging from 11.8 to $13.2 \%$ of $\mathrm{NEE}_{\mathrm{c}}$. For the freshwater marsh, maximum $U$ was $43.4 \mathrm{~g} \mathrm{CO}_{2}-\mathrm{C} \mathrm{m}^{2} \mathrm{yr}^{-1}$ for 2012 and 2013 , ranging from 10.5 to $13.2 \%$ of $\mathrm{NEE}_{\mathrm{c}}$.

Given the complications of developing subdaily $\mathrm{CH}_{4}$ correlations with hydrometeorological data [Shoemaker et al., 2015], $30 \mathrm{~min} \mathrm{CH}_{4}$ fluxes were averaged by day to estimate daily flux. To gap fill missing days, stepwise regression analysis was performed using meteorological and environmental covariates to predict daily $\mathrm{CH}_{4}$ flux (see Statistical Analysis) [Holm et al., 2016]. Of the $30 \mathrm{~min} \mathrm{CH}_{4}$ samples collected using EC, we retained $38 \%$ from the brackish marsh and 55\% from the freshwater marsh. Predicted to observed error based on daily $\mathrm{CH}_{4}$ fluxes equated to $14.3 \%$ (or $1.5 \mathrm{~g} \mathrm{CH}_{4}-\mathrm{C} \mathrm{m}^{2} \mathrm{yr}^{-1}$ ) of $\mathrm{NEE}_{\mathrm{c}}$ of $\mathrm{CH}_{4}$ for the brackish marsh and $19.5 \%$ (or $9.1 \mathrm{~g} \mathrm{CH}_{4}-\mathrm{C} \mathrm{m}^{2} \mathrm{yr}^{-1}$ ) of $\mathrm{NEE}_{\mathrm{c}}$ of $\mathrm{CH}_{4}$ for the freshwater marsh [Holm et al., 2016].

\subsection{Meteorological and Environmental Measurements}

In addition to $T_{\mathrm{a} \text {-tower, }}$ we installed two combination air and soil temperature probes. Air temperature was also measured just at the top of the marsh grass $\left(T_{\mathrm{a} \text {-marsh }}\right)$ and soil temperature $\left(T_{\mathrm{s}}\right)$ was measured just below the soil surface $(10 \mathrm{~cm}$ ) near each boardwalk at 15 min intervals using a data logger (model HOBO Pro v.2, Onset Computer Corp., Bourne, MA, USA). Water vapor mole fraction and relative humidity was measured with the LI-7200. Vapor pressure deficit $(D)$ was then calculated as the difference between ambient water vapor partial pressure (derived from the ideal gas law, using ambient water vapor mass density, the water vapor gas constant, and temperature) and the water vapor partial pressure at saturation. On-site water table depth (WTD) was measured at hourly intervals on each site using a continuous water level recorder (model \#138, Infinities USA Inc., Port Orange, FL, USA) inserted into a $7.6 \mathrm{~cm}$ diameter PVC pipe to a soil depth of approximately $0.8 \mathrm{~m}$. Continuous in-stream salinity, water temperature $\left(T_{\mathrm{w}}\right)$, and supplemental water level data (water elevation) from the brackish marsh were acquired from CRMS-Wetlands Station 2825 and from the freshwater marsh were acquired from CRMS-Wetlands Station 3166. All elevations relative to North American Vertical Datum (NAVD 88) were acquired from CRMS-adjusted water levels. Discharge data from the Davis Pond Mississippi River diversion, which influences the freshwater marsh at Salvador WMA, came from U.S. Geological Survey Station 295501090190400 near Boutte, Louisiana. Photosynthetically active radiation (PAR) data were derived from the nearest UV-B Monitoring and Research Program (UVMRP) site in Baton Rouge, Louisiana.

\subsection{Analyses}

\subsubsection{Statistical Analyses}

All data were analyzed using SAS (Version 9.1, SAS Institute, Cary, North Carolina, USA). For chamber data, differences by site in instantaneous elemental fluxes $\left(\mathrm{g} \mathrm{C}\right.$ or $\mathrm{N}$ ) of $\mathrm{CO}_{2}, \mathrm{CH}_{4}$, and $\mathrm{N}_{2} \mathrm{O}$ over time were determined ( $n=6$ per day) at hourly intervals (e.g., $\mathrm{gC} \mathrm{m}^{2} \mathrm{~h}^{-1}$ ) using a repeated measures analysis of variance. Chamber data were then converted to daily flux rates through summation and analyzed as elemental flux rates per unit area at daily intervals (e.g., $\mathrm{gC}^{-2} \mathrm{~d}^{-1}$ ).

For EC measurements, gap filling $30 \mathrm{~min} \mathrm{CO}_{2}$ data produced a continuous data set for all days. Specifically, the meteorological variables sensible heat, latent heat, PAR, $T_{\mathrm{a} \text {-tower }}, T_{\mathrm{s}}$, relative humidity, and $D$ were used in combination to gap fill. For days with no acceptable $\mathrm{CH}_{4}$ data, missing data were estimated by interpolation based upon statistically significant relationships between daily $\mathrm{CH}_{4}$ flux and measured meteorological or environmental variables [Holm et al., 2016]. Daily $\mathrm{CH}_{4}$ fluxes exhibited the strongest correlation $(p<0.001$ for all) with $T_{\mathrm{w}}, T_{\mathrm{s}}$, salinity, and $T_{\mathrm{a} \text {-tower }}$ for the brackish marsh, and with $T_{\mathrm{w}}, T_{\mathrm{s}}$, salinity, $T_{\mathrm{a} \text {-tower, }}$ and discharge from the freshwater diversion at Davis Pond for the freshwater marsh. The residuals of the models selected were then tested for normality and homogeneity of variance $(\alpha=0.01)$ and further tested for autocorrelation, and then an appropriate autoregressive integrated moving average model was fit $(\alpha=0.01)$.

\subsubsection{Formulation for Daily Gas Flux Determinations From Chambers}

To scale chamber fluxes, linear correlation analyses were first conducted on daily fluxes versus average $T_{\mathrm{s}}, T_{\mathrm{a}-\text { marsh }}$ $T_{\mathrm{a} \text {-tower, }}$ and WTD. Linear correlations were retained and further tested using square root and natural logarithmic transformations of these variables, along with salinity, discharge, and $T_{\mathrm{w}}$ data when applicable, over quarterly time intervals $(Q)$ to improve model fit using stepwise multiple regression procedures (Proc GLMSelect). Q was defined as March to May, June to August, September to November, or December 
to February. Groupings for $Q$ corresponded to time periods when fluxes were similar, reflecting seasonal activity in these fluxes. When significant, multifactorial models were used to predict chamber fluxes of $\mathrm{CO}_{2}, \mathrm{CH}_{4}$, and $\mathrm{N}_{2} \mathrm{O}$ on an annual basis. Otherwise, hourly flux data were summed to yield daily fluxes.

$Q$ and $T_{\mathrm{s}}$ were useful for predicting $\mathrm{CO}_{2}$ fluxes from the brackish marsh:

$$
\mathrm{CO}_{2}=\left[-37555.41+Q+12001.18 \times \ln \left(T_{s}+1\right)\right] / 1000,
$$

where $\mathrm{CO}_{2}$ is in $\mathrm{g} \mathrm{C} \mathrm{m}^{-2} \mathrm{~d}^{-1}, T_{\mathrm{s}}$ is in ${ }^{\circ} \mathrm{C}$, and $Q$ equals 2567.29 for predictions from March to May and 0.00 for predictions from June to August for the period sampled $\left(R^{2}=0.83 ; p=0.002\right)$. No significant equations were identified for $\mathrm{CH}_{4}$ or $\mathrm{N}_{2} \mathrm{O}$ from the brackish marsh so we were not able to predict these fluxes for days not sampled.

For the freshwater marsh, the following predictive equation was developed:

$$
\mathrm{CO}_{2}=\left[-990.09+4.15\left(T_{s}\right)^{2}-123.62(\mathrm{WTD})\right] / 1000,
$$

where $\mathrm{CO}_{2}$ is in $\mathrm{g} \mathrm{C} \mathrm{m}^{-2} \mathrm{~d}^{-1}$ and WTD is in centimeters $\left(R^{2}=0.79 ; p<0.001\right)$. $Q$ was not significant such that equation (4) can be used for prediction throughout the year. In contrast, fluxes of $\mathrm{CH}_{4}$ from the freshwater marsh were affected by $Q$ and mean WTD:

$$
\mathrm{CH}_{4}=[211.67+14.297(\mathrm{WTD})+Q] / 1000,
$$

where $\mathrm{CH}_{4}$ is in $\mathrm{g} \mathrm{C} \mathrm{m}^{-2} \mathrm{~d}^{-1}$ and $Q$ describes a step function equating to 156.25 for predictions from March to May, -68.56 for predictions from June to August, -12.36 for predictions from September to November, and 0.00 for predictions from December to February $\left(R^{2}=0.79 ; p<0.001\right)$. No significant predictive equations were identified for $\mathrm{N}_{2} \mathrm{O}$ from the freshwater marsh, so we were not able to predict these fluxes for days not sampled.

\section{Results}

\subsection{Hydrological Characterization}

Available hydrologic records over the study period indicated that major pulses of high water transcended the coastline to affect both brackish and freshwater marsh sites simultaneously, especially during a southern swell (June) and tropical storm event in late August (Hurricane Isaac) of 2012 (Figure 2). For the southern swell event, water levels increased by about $20 \mathrm{~cm}$ on both sites and persisted for approximately 1 month without dewatering, while the surge from Hurricane Isaac caused approximately $70-100 \mathrm{~cm}$ of flooding, gradually decreasing over the following week. While sites differed considerably in salinity regime $-<0.5$ versus 9 psu -mean flood frequency differed by only nine events per year. The freshwater marsh influenced by a freshwater diversion at Salvador WMA was flooded for only $81 \mathrm{~h} \mathrm{yr}^{-1}$ more than the brackish marsh at Pointe-aux-Chenes WMA, which had no diversion. An additional difference was that the surface of the freshwater marsh was semibuoyant (Figure 2), a common condition of this marsh type in Louisiana. While these sites are characterized as tidal (micro-), diurnal fluctuations are more obvious for the brackish marsh than for the freshwater marsh, which was dominated by wind tides. On-site, realized tidal range was extremely low for both sites (Figure 2).

\subsection{Instantaneous $\mathrm{CO}_{2}, \mathrm{CH}_{4}$, and $\mathrm{N}_{2} \mathrm{O}$ Fluxes From Chambers}

Instantaneous fluxes of $\mathrm{CO}_{2}$ ranged from 0.027 to $0.188 \mathrm{~g} \mathrm{C} \mathrm{m}^{-2} \mathrm{~h}^{-1}$ among five measurement periods for the brackish marsh and from -0.065 to $0.135 \mathrm{~g} \mathrm{C} \mathrm{m}^{-2} \mathrm{~h}^{-1}$ among 11 measurement periods for the freshwater marsh (Figure 3). Fluxes of $\mathrm{CO}_{2}$ differed significantly over time for both the brackish $(F=17.35 ; p=0.002)$ and freshwater marsh $(F=32.13 ; p<0.001)$, highlighting a net efflux of $\mathrm{CO}_{2}$ from chambers most prominently in April-June. In fact, only once was $\mathrm{CO}_{2}$ taken up during dark chamber measurements (freshwater marsh in March 2012), perhaps related to site flooding.

Neither fluxes of $\mathrm{CH}_{4}(p=0.094)$ nor fluxes of $\mathrm{N}_{2} \mathrm{O}(p=0.166)$ differed significantly over time for the brackish marsh. Measurements for both were most variable in May 2012 (Figure 3) when marsh vegetation established high biomass for the first time that season and flooding was persistent. Fluxes of $\mathrm{CH}_{4}(F=14.35 ; p<0.001)$, but not $\mathrm{N}_{2} \mathrm{O}(p>0.05)$, differed over time for the freshwater marsh and were highest in March and April of 2012. Fluxes of $\mathrm{CH}_{4}$ ranged from 0.001 to $0.026 \mathrm{~g} \mathrm{C} \mathrm{m}^{-2} \mathrm{~h}^{-1}$ for the brackish marsh and from 0.002 to $0.029 \mathrm{~g} \mathrm{C} \mathrm{m}^{-2} \mathrm{~h}^{-1}$ for the freshwater marsh, while fluxes of $\mathrm{N}_{2} \mathrm{O}$ ranged from -32.0 to $54.5 \mu \mathrm{g} \mathrm{N} \mathrm{m}^{-2} \mathrm{~h}^{-1}$ 

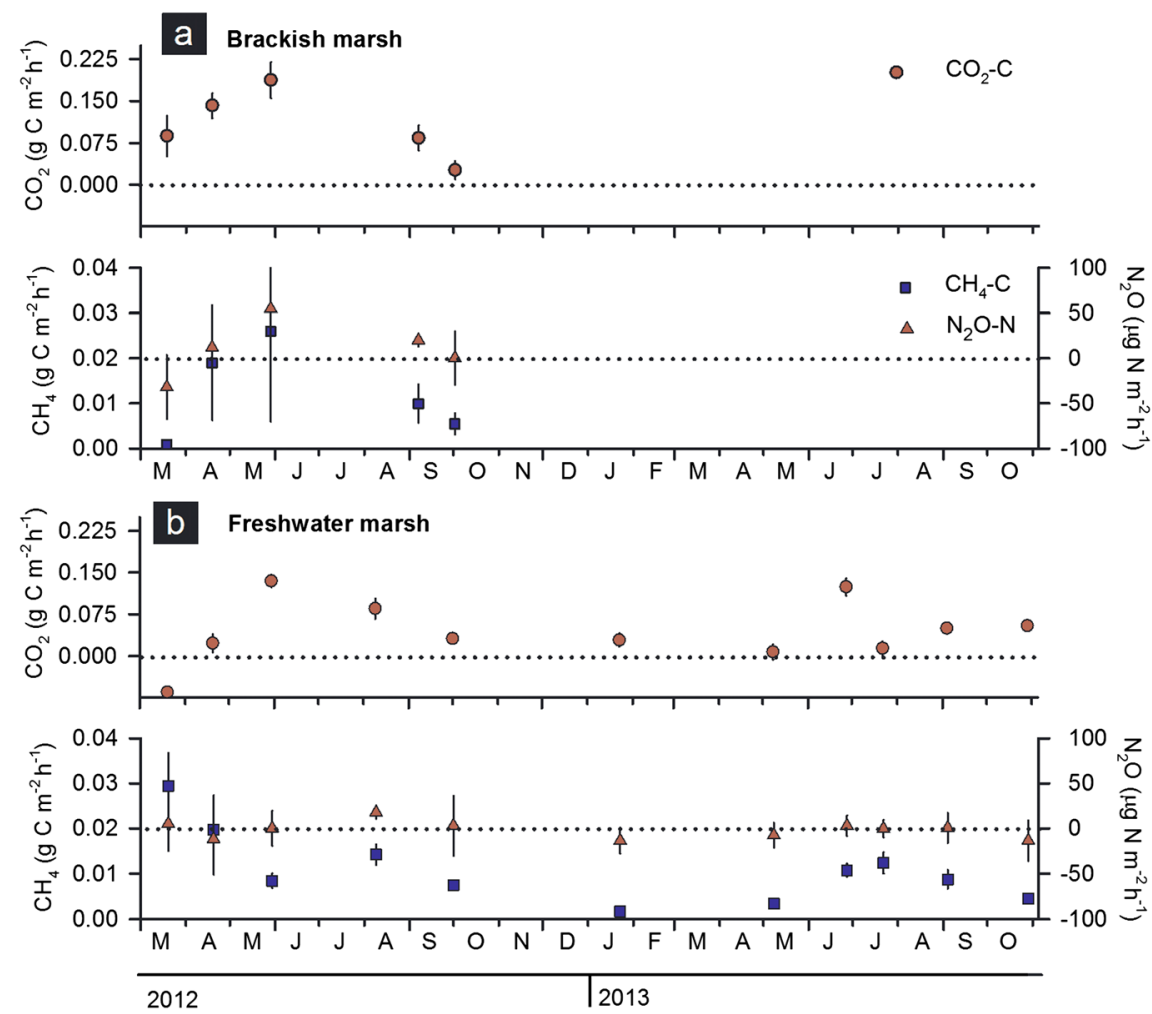

Figure 3. Mean instantaneous, hourly elemental chamber fluxes $( \pm 1 \mathrm{SE})$ of gaseous carbon $\left(\mathrm{CO}_{2}\right.$ and $\left.\mathrm{CH}_{4}\right)$ and nitrogen $\left(\mathrm{N}_{2} \mathrm{O}\right.$ ) from (a) brackish marsh and (b) freshwater marsh study sites in Louisiana. Negative $\mathrm{CO}_{2}, \mathrm{CH}_{4}$, or $\mathrm{N}_{2} \mathrm{O}$ flux values signify uptake by the marsh; positive values signify emissions from the marsh.

for the brackish marsh and from -13.7 to $17.9 \mu \mathrm{g} \mathrm{N} \mathrm{m}^{-2} \mathrm{~h}^{-1}$ for the freshwater marsh (Figure 3). While $\mathrm{CH}_{4}$ fluxes were consistently positive and vectored out of the soil, $\mathrm{N}_{2} \mathrm{O}$ fluxes were bidirectional.

Correlation analysis was used to identify the meteorological and environmental variables influencing $\mathrm{CO}_{2}$, $\mathrm{CH}_{4}$, and $\mathrm{N}_{2} \mathrm{O}$ fluxes through chambers. For the brackish marsh, two meteorological variables were autocor-

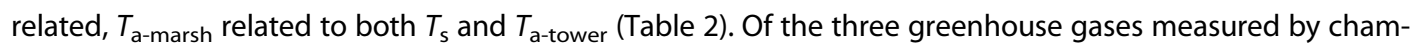
bers, $\mathrm{CO}_{2}$ was the only gas that correlated linearly to a meteorological or environmental variable, in this case WTD. More exposed soils (i.e., lower WTD) gave rise to greater fluxes of $\mathrm{CO}_{2} \cdot \mathrm{CH}_{4}$ and $\mathrm{N}_{2} \mathrm{O}$ correlated to nothing for the brackish marsh site (Table 2). For the freshwater marsh, the same meteorological variables that autocorrelated for the brackish marsh were observed, as well as two additional variables (Table 2), where $T_{\text {a-tower }}$ also correlated with $T_{\mathrm{s}}$. In addition, WTD correlated positively to $\mathrm{CH}_{4}$ fluxes and negatively to $\mathrm{CO}_{2}$ fluxes (Table 2), indicating that lower water tables give rise to greater $\mathrm{CO}_{2}$ fluxes relative to $\mathrm{CH}_{4}$ fluxes from chambers as soils became more exposed. Fluxes of $\mathrm{N}_{2} \mathrm{O}$ did not correlate to any meteorological or environmental variable.

\subsection{Daily Fluxes of $\mathrm{CO}_{2}, \mathrm{CH}_{4}$, and $\mathrm{N}_{2} \mathrm{O}$ From Chambers}

Over the record of chamber measurements, modeled daily $\mathrm{CO}_{2}$ fluxes from the brackish marsh mirrored seasonal patterns from instantaneous measurements in being highest in May-June, ranging from -1.78 to $5.11 \mathrm{~g} \mathrm{C} \mathrm{m}^{-2} \mathrm{~d}^{-1}$. We were not able to determine $\mathrm{CH}_{4}$ fluxes through modeling. However, based on individual hourly samples summed (Figure 3), $\mathrm{CH}_{4}$ fluxes from the brackish marsh averaged $0.14 \mathrm{~g} \mathrm{Cm}^{-2} \mathrm{~d}^{-1}$; this includes the exclusion of two outlier values ( $>3$ standard deviation of mean) from individual chambers over time. From the freshwater marsh, modeled $\mathrm{CO}_{2}$ fluxes ranged from -5.38 to $3.83 \mathrm{~g} \mathrm{C} \mathrm{m}^{-2} \mathrm{~d}^{-1}$ and $\mathrm{CH}_{4}$ fluxes ranged from -0.02 to $0.95 \mathrm{~g} \mathrm{C} \mathrm{m}^{-2} \mathrm{~d}^{-1}$ through chambers.

$\mathrm{N}_{2} \mathrm{O}$ fluxes through chambers were very low for both marshes and also had to be estimated based on individual hourly samples summed. Despite fewer samples for the brackish marsh than for the freshwater marsh, 
Table 2. Pearson Correlation Coefficients and $p$ Values for Daily Averaged Soil Greenhouse Gas Fluxes of $\mathrm{CO}_{2}, \mathrm{CH}_{4}$, and $\mathrm{N}_{2} \mathrm{O}$ Collected From Static Flux Chambers Versus Mean Daily Soil Temperature $\left(T_{\mathrm{s}}\right)$, Air Temperature Measured Just Above the Marsh ( $\left.T_{\mathrm{a} \text {-marsh }}\right)$, Air Temperature at the Eddy Covariance Tower $\left(T_{\mathrm{a} \text {-tower }}\right)$, and Water Table Depth (WTD) for (A) a Brackish Marsh Adjacent to Pointe-Aux-Chene WMA and (B) a Freshwater Marsh on Salvador WMA, Louisiana, USA ${ }^{a}$

(A) Brackish Marsh

(B) Freshwater Marsh

\begin{tabular}{|c|c|c|c|c|c|c|c|c|c|c|c|c|c|c|}
\hline & $\mathrm{CH}_{4}$ & $\mathrm{CO}_{2}$ & $\mathrm{~N}_{2} \mathrm{O}$ & $T_{\mathrm{s}}$ & $T_{\mathrm{a}-\mathrm{marsh}}$ & $T_{\text {a-tower }}$ & WTD & $\mathrm{CH}_{4}$ & $\mathrm{CO}_{2}$ & $\mathrm{~N}_{2} \mathrm{O}$ & $T_{\mathrm{s}}$ & $T_{\text {a-marsh }}$ & $T_{\mathrm{a} \text {-tower }}$ & WTD \\
\hline $\mathrm{CH}_{4}$ & 1.0000 & -- & -- & -- & -- & -- & -- & 1.0000 & -- & -- & -- & -- & -- & -- \\
\hline $\mathrm{CO}_{2}$ & $\begin{array}{c}0.2059 \\
0.568\end{array}$ & 1.0000 & -- & -- & -- & -- & -- & $\begin{array}{c}-0.4253 \\
0.062\end{array}$ & 1.0000 & -- & -- & -- & -- & -- \\
\hline $\mathrm{N}_{2} \mathrm{O}$ & $\begin{array}{c}0.4553 \\
0.186\end{array}$ & $\begin{array}{c}0.2130 \\
0.555\end{array}$ & 1.0000 & -- & -- & -- & -- & $\begin{array}{c}-0.0046 \\
0.985\end{array}$ & $\begin{array}{c}0.0669 \\
0.779\end{array}$ & 1.0000 & -- & -- & -- & -- \\
\hline$T_{\mathrm{s}}$ & $\begin{array}{c}0.1955 \\
0.588\end{array}$ & $\begin{array}{c}0.3897 \\
0.266\end{array}$ & $\begin{array}{c}0.4698 \\
0.171\end{array}$ & 1.0000 & -- & -- & -- & $\begin{array}{c}0.3227 \\
0.165\end{array}$ & $\begin{array}{c}0.3204 \\
0.168\end{array}$ & $\begin{array}{c}0.3232 \\
0.165\end{array}$ & 1.0000 & -- & -- & -- \\
\hline$T_{\text {a-marsh }}$ & $\begin{array}{c}0.3036 \\
0.394\end{array}$ & $\begin{array}{c}0.4352 \\
0.209\end{array}$ & $\begin{array}{l}0.3608 \\
0.306\end{array}$ & $\begin{array}{c}0.7832 \\
0.007\end{array}$ & 1.0000 & -- & -- & $\begin{array}{c}0.3306 \\
0.155\end{array}$ & $\begin{array}{c}0.2917 \\
0.212\end{array}$ & $\begin{array}{c}0.3359 \\
0.148\end{array}$ & $\begin{array}{l}0.9368 \\
<0.001\end{array}$ & 1.0000 & -- & -- \\
\hline$T_{\text {a-tower }}$ & $\begin{array}{c}0.3149 \\
0.376\end{array}$ & $\begin{array}{c}0.5807 \\
0.078\end{array}$ & $\begin{array}{c}0.3225 \\
0.364\end{array}$ & $\begin{array}{c}0.6299 \\
0.051\end{array}$ & $\begin{array}{l}0.9427 \\
<0.001\end{array}$ & 1.0000 & -- & $\begin{array}{c}0.3853 \\
0.093\end{array}$ & $\begin{array}{c}0.3327 \\
0.152\end{array}$ & $\begin{array}{c}0.2629 \\
0.263\end{array}$ & $\begin{array}{l}0.9405 \\
<0.001\end{array}$ & $\begin{array}{l}0.9794 \\
<0.001\end{array}$ & 1.0000 & -- \\
\hline WTD & $\begin{array}{c}-0.5573 \\
0.094\end{array}$ & $\begin{array}{c}-0.7148 \\
0.020\end{array}$ & $\begin{array}{c}-0.4784 \\
0.162\end{array}$ & $\begin{array}{c}-0.5320 \\
0.114\end{array}$ & $\begin{array}{c}-0.4510 \\
0.191\end{array}$ & $\begin{array}{c}-0.4301 \\
0.215\end{array}$ & 1.0000 & $\begin{array}{l}0.7867 \\
<0.001\end{array}$ & $\begin{array}{c}-0.6706 \\
0.001\end{array}$ & $\begin{array}{c}0.2214 \\
0.348\end{array}$ & $\begin{array}{c}0.3169 \\
0.174\end{array}$ & $\begin{array}{c}0.3214 \\
0.167\end{array}$ & $\begin{array}{c}0.2828 \\
0.227\end{array}$ & 1.0000 \\
\hline
\end{tabular}

${ }^{\mathrm{a}}$ Bold font indicates significant correlations

$\mathrm{N}_{2} \mathrm{O}$ fluxes ranged more broadly from the brackish marsh $\left(-420\right.$ to $1310 \mu \mathrm{g} \mathrm{N} \mathrm{m}^{-2} \mathrm{~d}^{-1}$ versus -330 to $430 \mu \mathrm{g} \mathrm{N} \mathrm{m}^{-2} \mathrm{~d}^{-1}$ for the freshwater marsh). $\mathrm{N}_{2} \mathrm{O}$ fluxes did not differ significantly from 0 on individual sampling days for either the brackish marsh ( $t$ test, $n=10 ; p=0.359)$ or the freshwater marsh $(n=20 ; p=0.596)$.

\subsection{Daily Fluxes of $\mathrm{CO}_{2}$ and $\mathrm{CH}_{4}$ From EC}

Over the record of EC measurements, $\mathrm{CO}_{2}$ fluxes ranged from -0.91 to $3.15 \mathrm{~g} \mathrm{C} \mathrm{m}^{-2} \mathrm{~d}^{-1}$ and $\mathrm{CH}_{4}$ fluxes ranged from -0.01 to $0.15 \mathrm{~g} \mathrm{C} \mathrm{m}^{-2} \mathrm{~d}^{-1}$ from the brackish marsh (Figure 4). Patterns depict some interannual variability. First, $\mathrm{CO}_{2}$ emissions were higher in October-November of 2011 than in the same months in 2012. Second, $\mathrm{CH}_{4}$ emissions were generally highest when $\mathrm{CO}_{2}$ emissions were lowest, corresponding to periods of low salinity in April-October of 2012 not as prevalent in 2011 . Third, $R_{\text {eco }}$ gradually increased from October 2011 to mid-February 2012 and decreased until March 2012. Then, $T_{\mathrm{s}}$ and $T_{\mathrm{a} \text {-tower }}$ increased to an apparent threshold level when rates of $R_{\text {eco }}$ nearly doubled rapidly over the ensuing 8 days to reach growing season values in April and into the summer.

Accordingly, $\mathrm{CO}_{2}$ fluxes ranged from -5.92 to $2.39 \mathrm{~g} \mathrm{C} \mathrm{m}^{-2} \mathrm{~d}^{-1}$ and $\mathrm{CH}_{4}$ fluxes ranged from -0.06 to $0.42 \mathrm{~g} \mathrm{C} \mathrm{m}^{-2} \mathrm{~d}^{-1}$ from the freshwater marsh (Figure 5). Patterns were fairly consistent between years. $\mathrm{CO}_{2}$ uptake was highest in April-August during the active growing season, which did tend to occur slightly before major $\mathrm{CH}_{4}$ emissions in June-September of 2012. $\mathrm{CO}_{2}$ uptake and $\mathrm{CH}_{4}$ efflux coincided much better in 2013. Higher rates of $R_{\text {eco }}$ tended to coincide with greater $\mathrm{CO}_{2}$ uptake and higher $T_{\mathrm{s}}$ and $T_{\mathrm{a} \text {-tower. }} \mathrm{NEE}_{\mathrm{c}}$ of $\mathrm{CO}_{2}$ and $R_{\text {eco }}$ balanced during winter months, concomitant also with near zero $\mathrm{CH}_{4}$ fluxes. Furthermore, $\mathrm{CH}_{4}$ emissions tended to be inversely related to discharge from the Davis Pond diversion, although this is confounded somewhat by the correspondingly lower $T_{\mathrm{s}}$ and $T_{\mathrm{a} \text {-tower }}$ during higher winter discharge periods (Figure 5). However, discharge and WTD were not strongly connected for the freshwater marsh site [Holm et al., 2016].

Specific drivers of $\mathrm{CH}_{4}$ and $\mathrm{CO}_{2}$ flux are highlighted through univariate analyses (Figure 6). Emissions of $\mathrm{CH}_{4}$ from both marshes increased exponentially with increasing $T_{\mathrm{s}}$, while $\mathrm{CO}_{2}$ uptake increased with increased $T_{\mathrm{s}}$ reflecting increased photosynthetic activity by plants on both sites. $D$ had no influence on $\mathrm{CH}_{4}$ emissions or $\mathrm{CO}_{2}$ flux from the brackish marsh; however, increasing $D$ yielded greater $\mathrm{CH}_{4}$ emissions and $\mathrm{CO}_{2}$ uptake from the freshwater marsh (Figure 6), highlighting the relative health of the freshwater marsh versus the brackish marsh. Increasing salinity from $\sim 2$ to 16 psu decreased $\mathrm{CH}_{4}$ flux from the brackish marsh, as well as from the freshwater marsh, even though salinity from the freshwater marsh ranged to only $0.41 \mathrm{psu}$. The relationship between salinity and $\mathrm{CO}_{2}$ flux was either highly variable without obvious pattern (brackish marsh) or not significant (freshwater marsh). Finally, increased water elevation stimulated $\mathrm{CH}_{4}$ emissions and $\mathrm{CO}_{2}$ uptake on both sites, although an inflection from higher to lower $\mathrm{CO}_{2}$ uptake at water elevations of $>0.6 \mathrm{~m}$ (NAVD 88) for both sites was observed, highlighting potentially greater flood stress on marsh vegetation growing on both sites. 

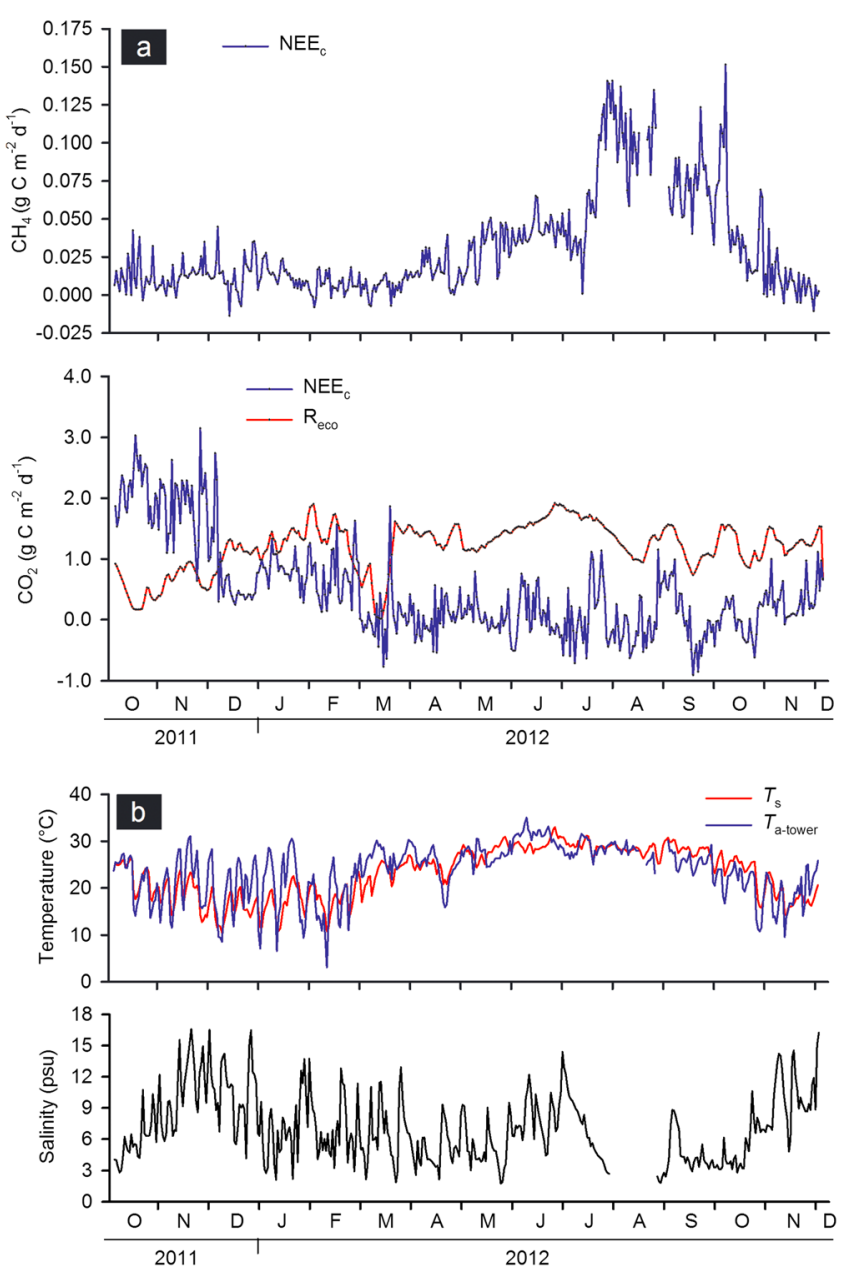

Figure 4. Overview of $\mathrm{NEE}_{\mathrm{c}}$ (from EC techniques) for the brackish marsh, Louisiana, USA, including (a) daily elemental fluxes of carbon from $\mathrm{CH}_{4}$ and $\mathrm{CO}_{2}$, along with ecosystem respiration of $\mathrm{CO}_{2}\left(R_{\text {eco }}\right)$, and (b) daily summary of relevant meteorological and/or environmental variables, including soil temperature $\left(T_{\mathrm{s}}\right)$, air temperature measured from the EC tower ( $T_{\mathrm{a} \text {-tower }}$ ), and salinity. Negative $\mathrm{CO}_{2}$ or $\mathrm{CH}_{4}$ flux values signify uptake by the marsh; positive values signify emissions from the marsh.

\subsection{Annual $\mathrm{NEE}_{\mathrm{c}}$ From EC Versus Chamber Fluxes}

Daily fluxes from EC and chambers were summed separately over the period of record and annualized. Using EC, the brackish marsh lost $181.7 \mathrm{~g} \mathrm{C} \mathrm{m}^{-2} \mathrm{yr}^{-1}$ and the freshwater marsh took up $-289.9 \mathrm{gC} \mathrm{m}^{-2} \mathrm{yr}^{-1}$ (Table 3). Of the $\mathrm{NEE}_{\mathrm{c}}$ of $181.7 \mathrm{~g} \mathrm{C} \mathrm{m}^{-2} \mathrm{yr}^{-1}$ for the brackish marsh, $11.1 \mathrm{~g} \mathrm{Cm}^{-2} \mathrm{yr}^{-1}$ is from $\mathrm{CH}_{4}$ emissions and the remaining $170.6 \mathrm{~g} \mathrm{Cm}^{-2} \mathrm{yr}^{-1}$ is from $\mathrm{CO}_{2}$ emissions. $R_{\text {eco }}$ emissions of $\mathrm{CO}_{2}$ were $434.4 \mathrm{~g} \mathrm{C} \mathrm{m}^{-2} \mathrm{yr}^{-1}$, suggesting that plant photosynthetic uptake (or GEP) accounts for approximately $-263.8 \mathrm{~g} \mathrm{Cm}^{-2} \mathrm{yr}^{-1}$ on the brackish marsh despite marsh deterioration. In contrast, respiratory $\mathrm{CO}_{2}$ emissions as estimated from chambers equated to an even higher $\mathrm{C}$ emissions rate of $1011.0 \mathrm{~g} \mathrm{Cm}^{-2} \mathrm{yr}^{-1}$ from the brackish marsh. Respiratory $\mathrm{CH}_{4}$ fluxes through chambers were estimated at $49.6 \mathrm{~g} \mathrm{C} \mathrm{m}^{-2} \mathrm{yr}^{-1}$ or $<5 \%$ of chamber $\mathrm{CO}_{2}$ fluxes of elemental $\mathrm{C}$. Together, $\mathrm{CO}_{2}$ and $\mathrm{CH}_{4}$ emissions from chambers equated to $1060.6 \mathrm{~g} \mathrm{C} \mathrm{m}^{-2} \mathrm{yr}^{-1}$ from the brackish marsh and were approximately 2.4 times higher than the combined respiratory emissions of $\mathrm{CO}_{2}\left(434.4 \mathrm{~g} \mathrm{C} \mathrm{m}^{-2} \mathrm{yr}^{-1}\right)$ plus $\mathrm{CH}_{4}$ $\left(11.1 \mathrm{gCm}^{-2} \mathrm{yr}^{-1}\right) \quad$ through EC (Table 3). $\mathrm{N}_{2} \mathrm{O}$ emissions were estimated from chambers as $0.12 \mathrm{~g} \mathrm{~N} \mathrm{~m}^{-2} \mathrm{yr}^{-1}$ for the brackish marsh.

Of the $\mathrm{NEE}_{\mathrm{c}}$ of $-289.9 \mathrm{~g} \mathrm{Cm}^{-2} \mathrm{yr}^{-1}$ taken up by the freshwater marsh, $47.1 \mathrm{~g} \mathrm{C} \mathrm{m}^{-2} \mathrm{yr}^{-1}$ was lost from $\mathrm{CH}_{4}$ emissions and $-337.0 \mathrm{~g} \mathrm{Cm}^{-2} \mathrm{yr}^{-1}$ of $\mathrm{CO}_{2}$ was taken up. $R_{\mathrm{eco}}$ emissions of $\mathrm{CO}_{2}$ were $893.0 \mathrm{~g} \mathrm{Cm}^{-2} \mathrm{yr}^{-1}$, suggesting that plant photosynthetic uptake (or $\sim \mathrm{GEP}$ ) accounts for approximately $-1230.0 \mathrm{~g} \mathrm{Cm}^{-2} \mathrm{yr}^{-1} \mathrm{from}$ the freshwater marsh. Respiratory $\mathrm{CH}_{4}$ fluxes from chambers were $91.9 \mathrm{~g} \mathrm{C} \mathrm{m}^{-2} \mathrm{yr}^{-1}$ or $26 \%$ of chamber $\mathrm{CO}_{2}$ fluxes of elemental $\mathrm{C}$. Together, $\mathrm{CO}_{2}$ and $\mathrm{CH}_{4}$ emissions from chambers equated to $449.9 \mathrm{~g} \mathrm{C} \mathrm{m}^{-2} \mathrm{yr}^{-1}$ from the freshwater marsh and represented only $48 \%$ of the combined respiratory emissions of $\mathrm{CO}_{2}$ (893.0 $\mathrm{g} \mathrm{C} \mathrm{m}^{-2} \mathrm{yr}^{-1}$ ) plus $\mathrm{CH}_{4}\left(47.1 \mathrm{~g} \mathrm{C} \mathrm{m}^{-2} \mathrm{yr}^{-1}\right.$ ) through EC (Table 3). $\mathrm{N}_{2} \mathrm{O}$ uptake rate was estimated from chambers as $-0.02 \mathrm{~g} \mathrm{~N} \mathrm{~m}^{-2} \mathrm{yr}^{-1}$ for the freshwater marsh.

\section{Discussion}

\subsection{EC Fluxes of Gaseous C From Coastal Louisiana Marshes and Other Locations}

Carbon was emitted to the atmosphere at a rate of $182 \mathrm{~g} \mathrm{Cm}^{-2} \mathrm{yr}^{-1}$ from the brackish marsh, comparing favorably with EC-based C emissions assessments from grazed degraded peatlands $\left(178-302 \mathrm{~g} \mathrm{C} \mathrm{m}^{-2} \mathrm{yr}^{-1}\right)$ [Hatala et al., 2012] and drained agricultural wetlands in the Sacramento-San Joaquin Delta of California 

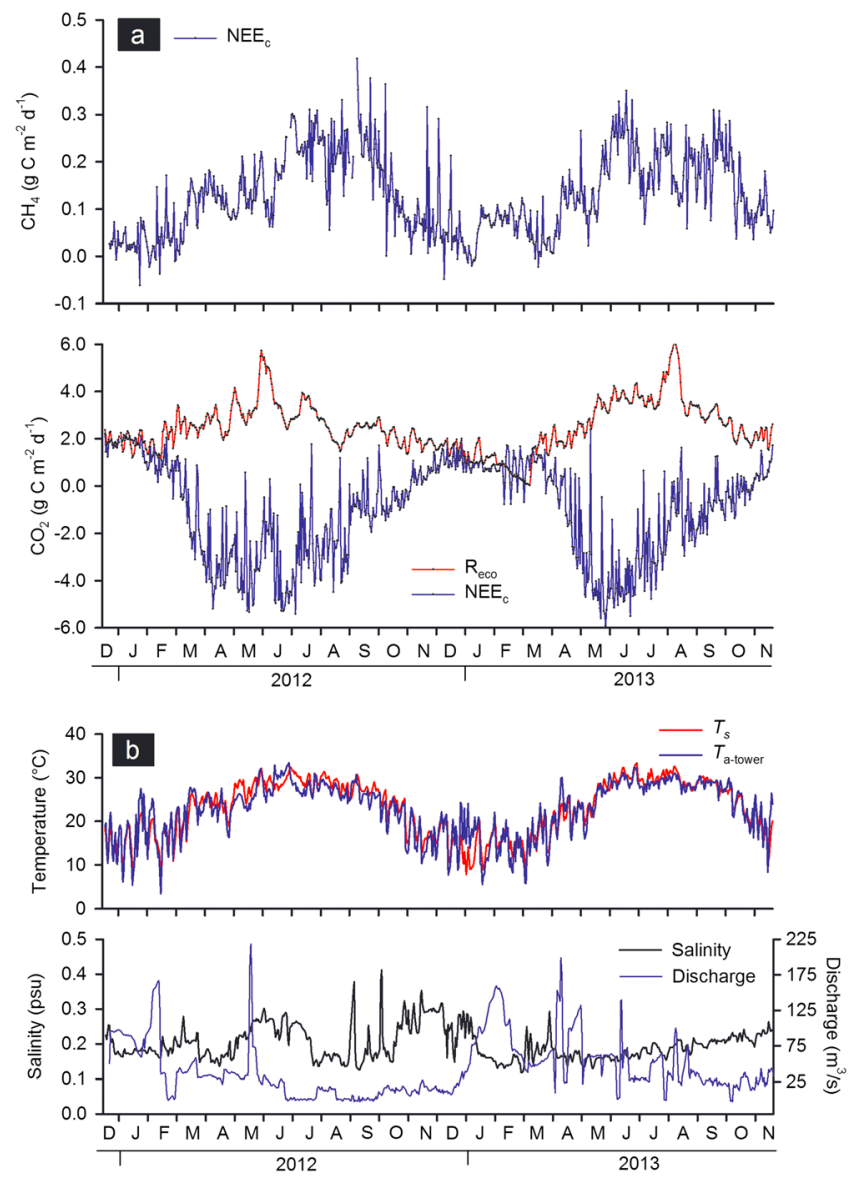

Figure 5. Overview of $\mathrm{NEE}_{\mathrm{c}}$ (from EC techniques) for the freshwater marsh, Louisiana, USA, including (a) daily elemental fluxes of carbon from $\mathrm{CH}_{4}$ and $\mathrm{CO}_{2}$, along with ecosystem respiration of $\mathrm{CO}_{2}\left(R_{\mathrm{eco}}\right)$, and (b) daily summary of relevant meteorological and/or environmental variables, including soil temperature $\left(T_{\mathrm{s}}\right)$, air temperature measured from the EC tower $\left(T_{\mathrm{a} \text {-tower }}\right)$, salinity, and discharge from the Davis Pond freshwater diversion. Negative $\mathrm{CO}_{2}$ or $\mathrm{CH}_{4}$ flux values signify uptake by the marsh; positive values signify emissions from the marsh. from $\mathrm{CO}_{2}$ emitted to $11 \mathrm{~g} \mathrm{C}$ from $\mathrm{CH}_{4}$ emitted) among those marshes reported by Mitsch et al. [2013], while on the flip side, this ratio was also fairly low (EC ratio: $-337 \mathrm{~g} \mathrm{C}$ from $\mathrm{CO}_{2}$ taken up to $47 \mathrm{~g} \mathrm{C}$ from $\mathrm{CH}_{4}$ emitted) for the freshwater marsh. These ratios are likely related to a combination of degradation of the brackish marsh facilitating organic matter mineralization and erosion and low salinity in the freshwater marsh facilitating high productivity with appreciable $\mathrm{CH}_{4}$ emissions. In more saline marshes, especially at salinity concentrations above 18 psu [Poffenbarger et al., 2011], $\mathrm{CH}_{4}$ emissions are universally suppressed. For example, $\mathrm{C}$ emissions from $\mathrm{CH}_{4}$ were only $0.02-0.11 \%$ of $\mathrm{C}$ emissions from $\mathrm{CO}_{2}$ in a Canadian tidal salt marsh [Chmura et al., 2011].

Even short-term experimental additions of salinity to freshwater marshes can change the balance of $\mathrm{CO}_{2}$ versus $\mathrm{CH}_{4}$ fluxes; $\mathrm{CH}_{4}$ emissions were reduced from 53 to $37 \mathrm{~g} \mathrm{Cm}^{-2} \mathrm{yr}^{-1}$ in a tidal freshwater marsh where the salinity was experimentally raised from freshwater to oligohaline levels for over 18 months [Neubauer, 2013]. Thus, fluctuating short-term salinity concentrations from 1.8 to $16.6 \mathrm{psu}$ was likely responsible for reducing the respiratory emissions of $\mathrm{CH}_{4}$ in our brackish marsh (Figure 6), an observation expected by past results in marshes developing along salinity gradients [Bartlett et al., 1987; DeLaune et al., 1983; Magenheimer et al., 1996; Poffenbarger et al., 2011]. Emissions of $\mathrm{CH}_{4}$ along our salinity gradient at the ecosystem level mirrored a statistical relationship developed from chamber-based studies [Poffenbarger et al., 2011; Holm et al., 2016], suggesting that the greater availability of sulfate $\left(\mathrm{SO}_{4}{ }^{2-}\right)$ as salinity concentrations increase also suppress $\mathrm{CH}_{4}$ emissions at the spatial scale measured by EC (Figure 6). 


\section{a Brackish marsh}
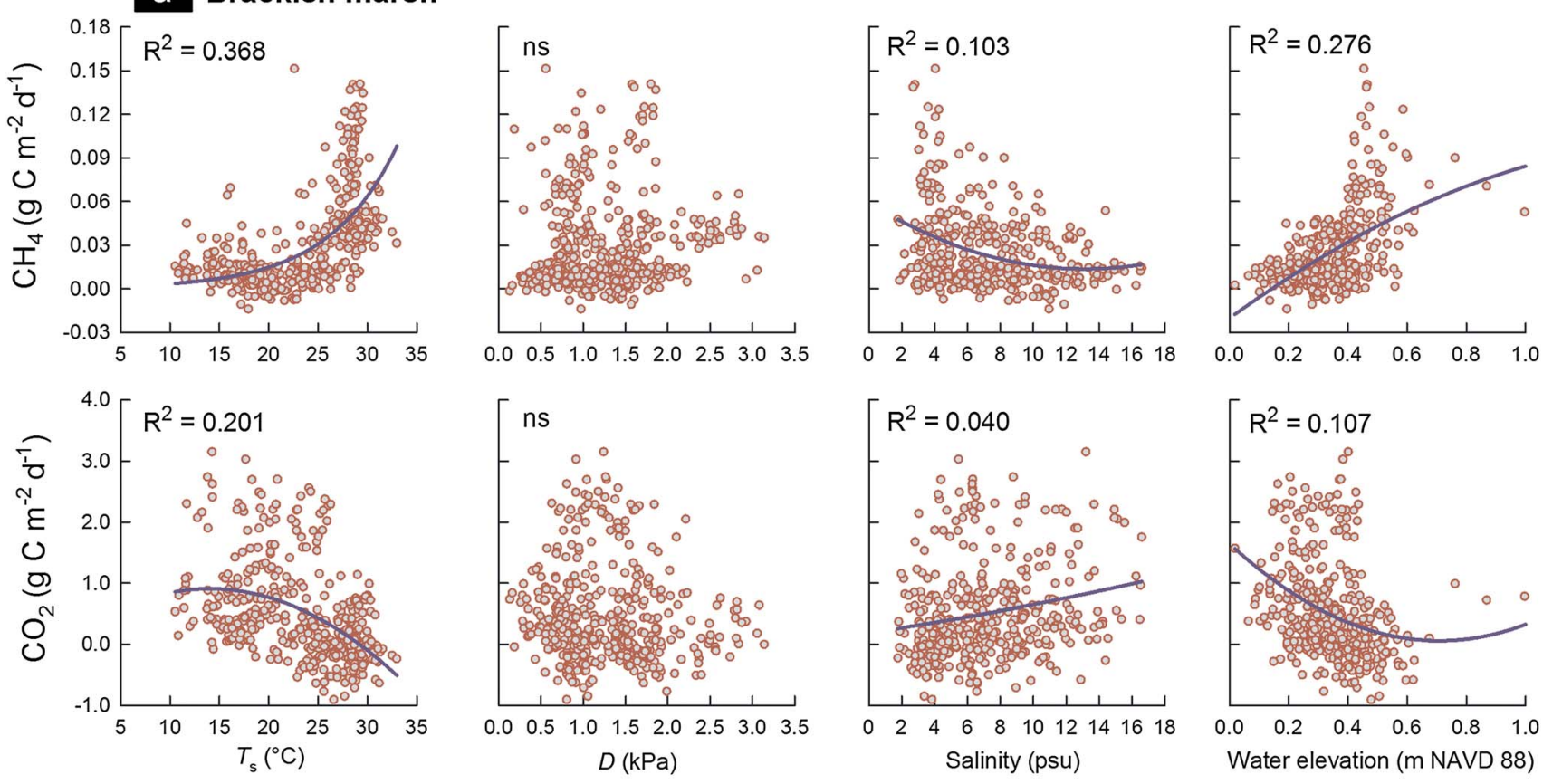

b Freshwater marsh
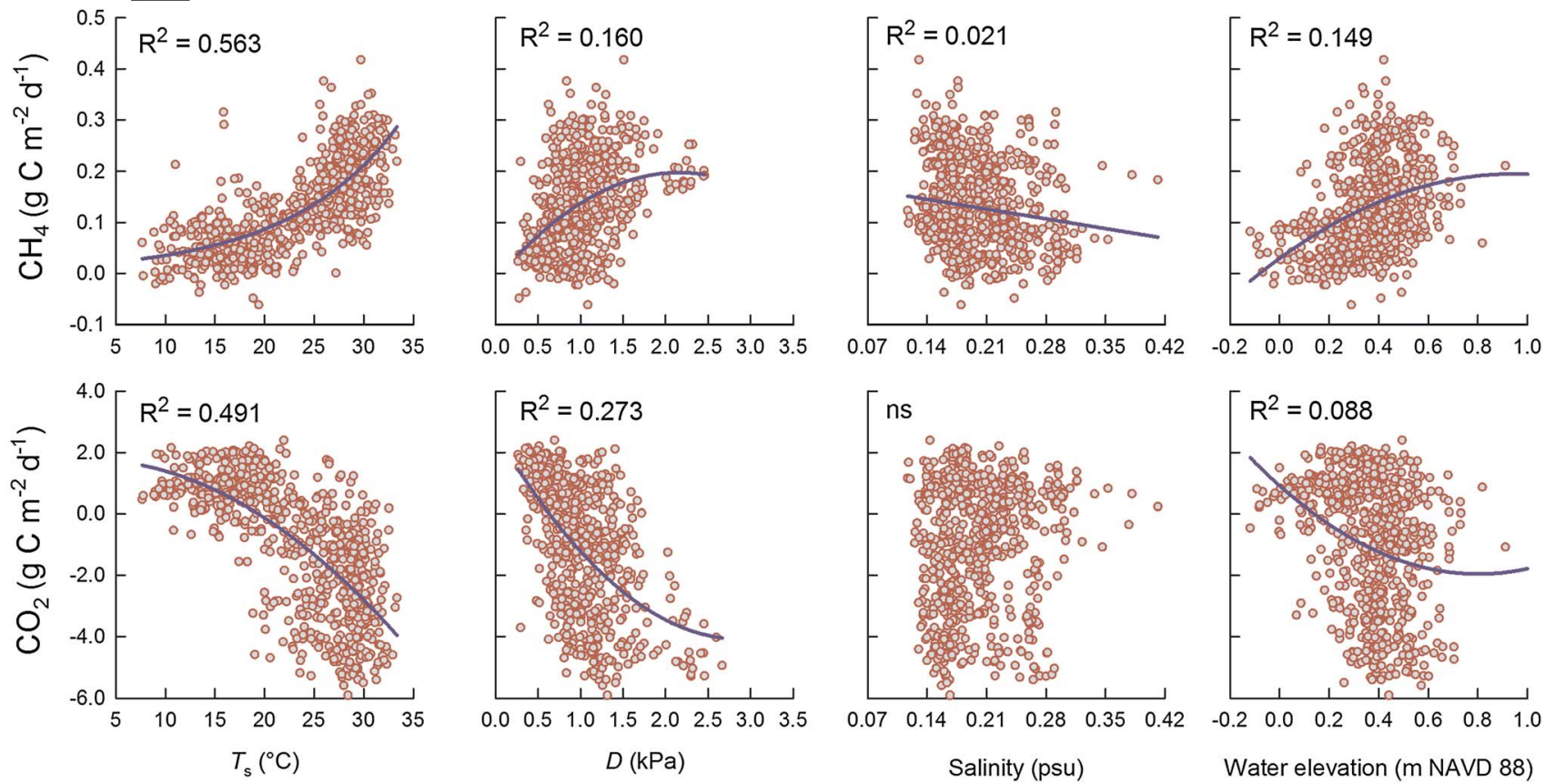

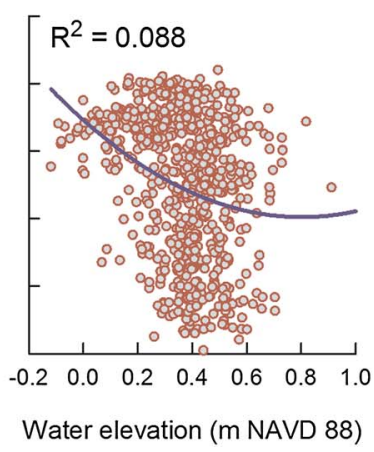

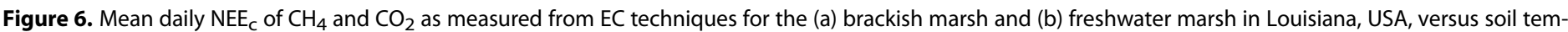

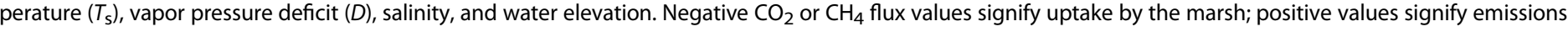
from the marsh.

Crozier and DeLaune [1996] showed that the most important factors for predicting $\mathrm{CH}_{4}$ emissions in these microtidal systems in Louisiana were temperature, labile $\mathrm{C}$ availability, and $\mathrm{SO}_{4}{ }^{2-}$ concentration. With the greater availability of $\mathrm{SO}_{4}{ }^{2-}$ with seawater, $\mathrm{SO}_{4}{ }^{2-}$ reduction becomes the dominant pathway for organic matter oxidation prompting increases in $\mathrm{CO}_{2}$ fluxes [Weston et al., 2006] and forcing the depletion of soil organic C stores [Weston et al., 2011]. Surprisingly, salinity also affected $\mathrm{CH}_{4}$ emissions in the freshwater marsh even though salinity remained below 0.5 psu (Figure 6). In this case, perhaps $\mathrm{CH}_{4}$ emissions were responding 
Table 3. Summary of Elemental Fluxes of $\mathrm{C}$ or $\mathrm{N}$ From $\mathrm{CO}_{2}, \mathrm{CH}_{4}$, and $\mathrm{N}_{2} \mathrm{O}$ Separated by Ecosystem Contribution Using Eddy Covariance ( $\mathrm{NEE}_{\mathrm{c}}$ ) and Static Chambers for a Brackish Marsh Adjacent to Pointe-aux-Chene WMA and a Freshwater Marsh on Salvador WMA, Louisiana, USA ${ }^{a}$

\begin{tabular}{lccc} 
& & \multicolumn{2}{c}{ Elemental Fluxes $\left(\mathrm{g} \mathrm{Cor}^{-2} \mathrm{yr}^{-1}\right)$} \\
\cline { 3 - 4 } Spatial Scale & Flux & Brackish Marsh & Freshwater Marsh \\
\hline \multirow{2}{*}{$\mathrm{NEEC}$} & $\mathrm{CH}_{4}$ & 11.1 & 47.1 \\
& $\mathrm{CO}_{2}$ & 170.6 & -337.0 \\
& $\mathrm{Net} \mathrm{C} \mathrm{flux}$ & 181.7 & -289.9 \\
& $R_{\text {eco }}$ & 434.4 & 893.0 \\
Chamber & $\mathrm{GEP}^{\mathrm{C}}$ & -263.8 & -1230.0 \\
& $\mathrm{CH}_{4}$ & 49.6 & 91.9 \\
& $\mathrm{CO}_{2}$ & 1011.0 & 357.9 \\
& $\mathrm{Net} \mathrm{soil} \mathrm{C} \mathrm{flux}$ & 1060.6 & 449.9 \\
& $\mathrm{~N} 2 \mathrm{O}$ & 0.12 & -0.02 \\
\hline
\end{tabular}

\footnotetext{
${ }^{\mathrm{a}}$ Negative values correspond to net uptake.

${ }^{\mathrm{b}} \mathrm{Net} \mathrm{C}$ flux is calculated as the sum of $\mathrm{CH}_{4}$ emissions and $\mathrm{CO}_{2}$ uptake/ release.

${ }^{\mathrm{C}}$ Gross ecosystem productivity (GEP) is calculated as $\mathrm{NEE}_{\mathrm{c}}$ of $\mathrm{CO}_{2}$ minus $R_{\text {eco. }}$
}

more to differences in specific conductivity from the river diversion in lieu of salinity per se; there is no direct evidence that such a low salinity range would influence $\mathrm{CH}_{4}$ emissions appreciably.

\subsection{Comparing EC Versus Chamber Techniques}

We expected emissions of $\mathrm{CH}_{4}$ to be similar among techniques since both techniques measure mostly the net loss of $\mathrm{CH}_{4}$ from wetland ecosystems; plants do not take up $\mathrm{CH}_{4}$. That $\mathrm{CH}_{4}$ fluxes were 2-4 times higher when measured by chambers versus EC in our study is important to note, especially when reviewing the literature. Other studies have also documented greater $\mathrm{CH}_{4}$ emissions when assessed by chambers versus EC. For example, $\mathrm{CH}_{4}$ emissions ranged from 18 to $91 \%$ higher (mean, 30\% higher) as assessed by small chambers versus EC from a rice field in Northern Italy [Meijide et al., 2011]. Since $\mathrm{CH}_{4}$ has an atmospheric lifetime of approximately 12 years [Myhre et al., 2013], $\mathrm{CH}_{4}$ released from the soil would not oxidize to $\mathrm{CO}_{2}$ appreciably before reaching the $\mathrm{EC}$ sensor at 3.4-3.6 m. However, at least three other explanations for the disparate values between EC and chamber techniques can be proposed. First, along with $\mathrm{CH}_{4}$ emitted directly from the soil surface, wetland plants vector $\mathrm{CH}_{4}$ to the atmosphere from deeper soils [Whiting and Chanton, 1993; Vann and Megonigal, 2003; Gauci et al., 2010; Pangala et al., 2013]. In locations with a prominent methanotrophic bacterial community, such as strongly tidal freshwater wetlands, up to $52-81 \%$ of $\mathrm{CH}_{4}$ produced in situ undergoes re oxidation back to $\mathrm{CO}_{2}$ prior to being released from the soil [Megonigal and Schlesinger, 2002]. Both of our marshes were tidal, but with smaller lunar tides, larger wind tides, and longer flood durations than is typical of Atlantic coastal tidal freshwater marshes, with some exception. The use of dark chambers might influence the role of the plant in vectoring $\mathrm{CH}_{4}$ from deeper soils to the atmosphere by bypassing zones of bacterially mediated methanotrophy; however, one would hypothesize that the effect would be to further reduce fluxes of $\mathrm{CH}_{4}$ from chambers (in the sense of Magenheimer et al. [1996]) relative to EC techniques, not enhance them as we show here.

Second, the spatial footprint of EC and chambers are vastly different. This should be noted since the majority of $\mathrm{CH}_{4}$ (and $\mathrm{CO}_{2}$ ) assessments are point based using chambers that are rarely replicated well over time, including our current study [see also Neubauer et al., 2000]. We used six chambers per site for each measurement period as our sample unit, which represents a total area of $0.52 \mathrm{~m}^{2}\left(0.0864 \mathrm{~m}^{2}\right.$ per chamber), and only measured fluxes 5-11 times. While chambers include some exposed water associated with culms of vegetation, the percentage of open water, bare soils, and vegetation differs greatly over larger spatial scales targeted by the EC system [e.g., Budishchev et al., 2014]. Likewise, only a fraction of the temporal environmental variability is included in chamber studies.

Third, and related, chamber data were collected exclusively during midday (1000-1600) when $\mathrm{CH}_{4}$ fluxes are inherently higher overall. For example, respiratory $\mathrm{CH}_{4}$ emissions were at least twice as high during the day as compared to night emissions in a tidal freshwater marsh in Virginia, USA [Neubauer et al., 2000]. EC calculations integrate night and day. Issues associated with spatial and temporal sampling resolution are also quite prevalent when comparing $R_{\text {eco }}$ data from EC with respiratory $\mathrm{CO}_{2}$ emissions from chambers for both sites (Table 3); yet applying chambers as we did to estimate soil $\mathrm{CO}_{2}$ emissions is common (Livingston and Hutchinson [1995], Yu et al. [2008], Moseman-Valtierra et al. [2011], Krauss and Whitbeck [2012], Olsson et al. [2015], etc.). With chamber estimates of respiratory $\mathrm{CO}_{2}$ emissions ranging from less than half to more than twice as high as EC estimation of $R_{\text {eco, }}$ disparities may be quite difficult to reconcile in the literature if these results are repeated. Greater replication of chamber measurements from our sites over time may have closed 
the gap in $\mathrm{CH}_{4}$ and $R_{\text {eco }}\left(\mathrm{CO}_{2}\right.$ emissions) estimates from chambers versus EC (as in Meijide et al. [2011]). Part of the issue for our brackish marsh, where the EC versus chamber fluxes varied the greatest, was certainly related to fairly limited temporal sampling from chambers $(n=5)$. More studies that compare these techniques are critical; however, good discussion of spatial sampling variability is already becoming more and more the focus of greenhouse gas emissions research [e.g., Forbrich et al., 2011; Meijide et al., 2011; Budishchev et al., 2014].

\subsection{Relating Greenhouse Gas Fluxes to the Process of Marsh Degradation}

Brackish and freshwater marshes in Louisiana have inherently different capacities for regulating fluxes of $\mathrm{CO}_{2}$ and $\mathrm{CH}_{4}$, as we document here. Earlier studies showed that brackish marshes of the Barataria Basin, Louisiana, emitted $73 \mathrm{~g} \mathrm{C} \mathrm{m}^{-2} \mathrm{yr}^{-1}$ as $\mathrm{CH}_{4}$, while freshwater marshes emitted $160 \mathrm{~g} \mathrm{C} \mathrm{m}^{-2} \mathrm{yr}^{-1}$ as $\mathrm{CH}_{4}$ [DeLaune et al., 1983]; these rates were about 1.5-1.7 times higher than our chamber fluxes and much higher than our EC fluxes (Table 3). On the other hand, $\mathrm{CO}_{2}$ emissions were lower from cores collected from brackish marshes $\left(228 \mathrm{~g} \mathrm{C} \mathrm{m}^{-2} \mathrm{yr}^{-1}\right)$ versus freshwater marshes $\left(780 \mathrm{~g} \mathrm{C} \mathrm{m}^{-2} \mathrm{yr}^{-1}\right)$ in past study [Nyman and DeLaune, 1991], better echoing our $R_{\text {eco }}$ results from EC towers than from chambers. It is uncertain exactly why our chamber data were opposite to this trend (Table 3), but we suspect that it has to do with the observation that our brackish marsh was not healthy with tremendous spatial variability in response. Nyman and DeLaune [1991] related differences between their marsh types to plant species composition and to the quality of soil organic matter, where the latter is most applicable to our results.

We also determined GEP (or gross photosynthetic uptake) of $\mathrm{CO}_{2}$ from EC. The brackish marsh took up $-264 \mathrm{~g} \mathrm{C} \mathrm{m}^{-2} \mathrm{yr}^{-1}$ as GEP (Table 3). This is considerably lower than chamber-based estimates of GEP (uptake of -650 to $-1000 \mathrm{~g} \mathrm{C} \mathrm{m}^{-2} \mathrm{yr}^{-1}$ ) in mesohaline and polyhaline marshes along the Atlantic and Gulf coasts of the U.S. [Miller et al., 2001; Weston et al., 2014; Wilson et al., 2015]. Technique disparity aside, reduced GEP from the Louisiana brackish marsh suggests that reductions in ecosystem carbon fixation is an important factor in the net emissions of $\mathrm{C}\left(182 \mathrm{~g} \mathrm{C} \mathrm{m}^{-2} \mathrm{yr}^{-1}\right)$ as our brackish marsh site is challenged to keep up with land submergence. Deposition of vegetative debris (wrack) from storms onto a brackish marsh caused a similar reduction in GEP (to $-280 \mathrm{~g} \mathrm{C} \mathrm{m}^{-2} \mathrm{yr}^{-1}$ ) and led to net $\mathrm{C}$ emissions of $222 \mathrm{~g} \mathrm{C} \mathrm{m}^{-2} \mathrm{yr}^{-1}$ in coastal Virginia [Miller et al., 2001]. However, it is important to note that net emissions of $C$ to the atmosphere do not necessarily mean that a site is deteriorating. In healthy tidal marshes in Alabama and Virginia, $R_{\text {eco }}$ exceeded gross production due to high inputs of allochthonous carbon that subsequently was mineralized in the marsh [Neubauer et al., 2000; Wilson et al., 2015].

In contrast to the brackish marsh, the plant community of the freshwater marsh took up $-1230 \mathrm{gC} \mathrm{m}^{-2} \mathrm{yr}^{-1}$ as GEP as estimated using EC (Table 3). This rate is typical of tidal freshwater marshes from New Jersey to Alabama, which had GEP rates of -750 to $-1500 \mathrm{~g} \mathrm{C} \mathrm{m}^{-2} \mathrm{yr}^{-1}$ [Neubauer et al., 2000; Neubauer, 2013; Weston et al., 2014; Wilson et al., 2015]. Instead of losing C to the atmosphere, the freshwater marsh at Salvador WMA is taking up $-290 \mathrm{~g} \mathrm{C} \mathrm{m}^{-2} \mathrm{yr}^{-1}$, a rate that is similar to long-term rates of soil $\mathrm{C}$ sequestration in tidal freshwater marshes (typically $\sim 100-300 \mathrm{~g} \mathrm{C} \mathrm{m}^{-2} \mathrm{yr}^{-1}$ as calculated from Neubauer [2008]). Therefore, our freshwater marsh was taking up atmospheric $C$ at a high rate fed by a much higher rate of photosynthesis than observed at the brackish marsh to facilitate net $C$ sequestration.

As tidal marshes deteriorate, they can experience reduced primary production, enhanced carbon emissions, net loss of surface elevation, and subsurface changes. A deteriorating salt marsh in New York was found to have less root and rhizome biomass, larger diameter rhizomes, reduced soil consolidation, and, like our brackish marsh, higher soil $\mathrm{CO}_{2}$ emissions than a nearby stable marsh [Wigand et al., 2014]. Stability of the deteriorating marsh was attributed to a balance among surface accretion of sediments, enhanced individual rhizome diameters, and swelling of surficial peats to facilitate greater soil volume expansion to survive submergence in the New York marsh system. Indeed, the root production for brackish S. patens marsh at Pointe-aux-Chenes probably was contracting as the plants formed shrinking clumps with bare areas between clumps, although aboveground tissue was still relatively prolific. This growth pattern may be a negative belowground response of this species to inundation [Snedden et al., 2015], driving an overall loss of C to the atmosphere, and, while unmeasured in this study, perhaps even greater losses to dissolved organic C through export [Bergamaschi et al., 2012].

\subsection{Perspectives on Radiative Forcing From Louisiana Deltaic Marshes}

In the simplest terms, the climatic role of ecosystems is determined using global warming potentials (GWPs) to convert rates of greenhouse gas uptake and emissions to a common currency (g CO $\mathrm{CO}_{2}$ equivalents). $\mathrm{CH}_{4}$ and $\mathrm{N}_{2} \mathrm{O}$ 
Table 4. The Radiative Balance of the Brackish and Freshwater Marsh Sites Based on Ecosystem $\mathrm{CH}_{4}$, Net $\mathrm{C}$ Fluxes, and Soil $\mathrm{N}_{2} \mathrm{O}$ Fluxes $(\text { Table } 3)^{\mathrm{a}}$

Radiative Fluxes (GWP)

\begin{tabular}{|c|c|c|c|c|}
\hline \multirow[b]{2}{*}{ Flux $\left(\mathrm{gCO}_{2}\right.$-eq $\left.\mathrm{m}^{-2} \mathrm{yr}^{-1}\right)$} & & \\
\hline & Brackish & Freshwater & Brackish & Freshwater \\
\hline $\mathrm{CH}_{4}$ & 444.0 & 1885.2 & 666.0 & 2827.8 \\
\hline Net $C$ flux & 666.2 & -1063.0 & 666.2 & -1063.0 \\
\hline $\mathrm{N}_{2} \mathrm{O}$ & 50.4 & -9.6 & 51.3 & -12.6 \\
\hline Net radiative balance & 1160.6 & 812.7 & 1383.6 & 1752.2 \\
\hline
\end{tabular}

${ }^{a}$ We first calculated radiative fluxes with the older approach of using global warming potentials (GWPs), which assumes that gases are emitted only as a single pulse at the beginning of the period of interest. We used 100 year GWP values of 30 and 265 for $\mathrm{CH}_{4}$ and $\mathrm{N}_{2} \mathrm{O}$, respectively [Myhre et al., 2013]. Positive numbers indicate a net warming effect; negative numbers indicate net cooling. For comparison, radiative fluxes $\left(\mathrm{g} \mathrm{CO}_{2}\right.$-eq $\left.\mathrm{m}^{-2} \mathrm{yr}^{-1}\right)$ were also calculated using sustained-flux global warming and global cooling potentials (SGWP and SGCP), which are based more appropriately on continuous fluxes of gases over a 100 year period [Neubauer and Megonigal, 2015].

are greenhouse gases with 100 year GWP values 30 times and 265 times greater than $\mathrm{CO}_{2}$, respectively $[$ Myhre et al., 2013]. Using these GWPs and applying them to EC data, we calculate that the brackish marsh is contributing the equivalent of $1161 \mathrm{~g} \mathrm{CO}_{2}$-eq $\mathrm{m}^{-2} \mathrm{yr}^{-1}$ to the atmosphere and the freshwater marsh is contributing the equivalent of $813 \mathrm{~g} \mathrm{CO}_{2}$-eq m${ }^{-2} \mathrm{yr}^{-1}$ to the atmosphere (that is, both are contributing to net warming, not cooling) (Table 4). However, the application of GWPs assumes that greenhouse gas emissions involve simple pulses that are not sustained annually, that uptake and emissions contribute similarly to radiative forcing with opposite signs, and that forcing occurs over specified time frames [Frolking et al., 2006; Neubauer and Megonigal, 2015].

In contrast, Neubauer and Megonigal [2015] proposed the use of the sustained-flux global warming potential (SGWP) [see also Fuglestvedt et al., 1996] for gas emissions and the sustained-flux global cooling potential (SGCP) for gas uptake. These metrics consider persistent greenhouse gas fluxes (rather than a single pulse) and account for asymmetry in radiative behavior between uptake and emissions fluxes. Over a 100 year period at our freshwater marsh site, the sustained-flux metrics indicate that this site emits the equivalent of $1752 \mathrm{~g} \mathrm{CO}_{2}$-eq $\mathrm{m}^{-2} \mathrm{yr}^{-1}$ to the atmosphere (net warming) whereas the GWP suggested that this influence is $54 \%$ less (Table 4), a disparity driven by $\mathrm{CH}_{4}$ accounting. In a qualitative sense, both sets of metrics also indicated that the brackish marsh had a strong net warming effect, although the strength of that warming differed by roughly $19 \%$ depending on the choice of sustained-flux $\left(1384 \mathrm{~g} \mathrm{CO}_{2}\right.$-eq m$\left.{ }^{-2} \mathrm{yr}^{-1}\right)$ versus pulse metrics $\left(1161 \mathrm{~g} \mathrm{CO}_{2}\right.$-eq $\left.\mathrm{m}^{-2} \mathrm{yr}^{-1}\right)$. Both marshes were net radiative sources over a 100 year period (Table 4), despite appreciable rates of GEP in both systems and net $C$ sequestration in the freshwater marsh (Table 3).

In the longer term, the warming from wetland greenhouse gas emissions eventually will be offset by longterm C sequestration [Neubauer, 2014; Petrescu et al., 2015]. The time when the marsh switches from having a lifetime net warming effect to a net cooling effect is known as the radiative forcing switchover time (in the sense of Frolking et al. [2006]), which happens because $\mathrm{CH}_{4}$ and $\mathrm{N}_{2} \mathrm{O}$ burdens will eventually reach steady state in the atmosphere, whereas the cumulative $\mathrm{C}$ storage in wetlands will increase from year to year. The switchover time for our freshwater marsh site is 376 years (calculated following the model in Neubauer [2014], as updated in Neubauer and Megonigal [2015]). Since the age of Holocene basal peat depths in the upper Barataria Basin exceeds this switchover time (>2250 years B.P. versus 376 years) [Kosters et al., 1987], we conclude that over the lifetime of the freshwater marsh, the cooling effect due to its $C$ sequestration and $\mathrm{N}_{2} \mathrm{O}$ uptake has exceeded the warming due to its $\mathrm{CH}_{4}$ emissions. A switchover time could not be calculated for the brackish marsh since there was no net uptake for any of the three greenhouse gases we considered. In other words, unless processes change in the brackish marsh such that there is net $C$ sequestration, this site will continue to have a positive (warming) radiative effect.

\section{Conclusions}

When scaled, emissions of $C$ to the atmosphere equated to $1817 \mathrm{~kg} \mathrm{Cha}^{-1} \mathrm{yr}^{-1}$ from the brackish marsh, and uptake of $\mathrm{C}$ equated to $2899 \mathrm{~kg} \mathrm{Cha}^{-1} \mathrm{yr}^{-1}$ from the freshwater marsh. Partitioning between uptake of $\mathrm{CO}_{2}$ and emissions of $\mathrm{CO}_{2}$ and $\mathrm{CH}_{4}$ was quite different between these two marsh types, driven by much greater GEP from the freshwater versus brackish marsh. We also discovered that net fluxes of $\mathrm{CH}_{4}$ and of respiratory 
$\mathrm{CO}_{2}$ emissions as estimated through EC differed from emissions as estimated with chamber techniques, identifying a potentially prominent source of variation in greenhouse gas flux estimation within the wetland literature. Emissions of $\mathrm{N}_{2} \mathrm{O}$ were insignificant from both marshes. As calculated using sustained-flux greenhouse gas metrics, the radiative balance over a 100 year time frame was positive (net warming) for both marshes but was considerably larger from the brackish marsh. Assuming that the fluxes described herein were maintained over time, the freshwater marsh would switch to having a net cooling effect after 376 years, implying that there are climatic benefits associated with preserving healthy wetlands.

\section{Acknowledgments}

Data from this study are available from Ken W. Krauss (USGS, chambers: kkrauss@usgs.gov) and Richard C. Raynie (CPRA, eddy covariance: Richard Raynie@la.gov) upon request. Funding for this research was provided by Louisiana Coastal Protection and Restoration Authority, USGS Climate and Land Use Change R\&D Program, and USGS LandCarbon Program. We thank the Louisiana Department of Wildlife and Fisheries for allowing access to study sites, as well as Apache Louisiana Minerals (through agreement with $\mathrm{CH} 2 \mathrm{M}$ ) for allowing us to install studies on their lands immediately adjacent to Pointe-aux-Chenes WMA. We thank Brian Bergamaschi, Ankur Desai, and three anonymous referees for providing excellent reviews of previous manuscript drafts, as well as Brady Couvillion for extracting Louisianaspecific marsh area estimates from Enwright et al. [2015]. Any use of trade, product, or firm names is for descriptive purposes only and does not imply endorsement by the U.S. Government.

\section{References}

Anderson, F. E., et al. (2016), Variation of energy and carbon fluxes from a restored temperate freshwater wetland and implications for carbon market verification protocols, J. Geophys. Res. Biogeosci., 131, 777-795, doi:10.1002/2015JG003083.

Archer, D. (2010), The Global Carbon Cycle, Princeton Univ. Press, Princeton, N. J.

Artigas, F., J. Y. Shin, C. Hobble, A. Marti-Donati, K. V. R. Schäfer, and I. Pechmann (2015), Long term carbon storage potential and $\mathrm{CO}_{2}$ sink strength of a restored salt marsh in New Jersey, Agric. For. Meteorol., 200, 313-321, doi:10.1016j.agrformet.2014.09.012.

Bartlett, K. B., D. S. Bartlett, R. C. Harriss, and D. I. Sebacher (1987), Methane emissions along a salt marsh salinity gradient, Biogeochemistry, 4(3), 183-202, doi:10.1007/BF02187365.

Bergamaschi, B. A., D. P. Krabbenhoft, G. R. Aiken, E. Patino, D. G. Rumbold, and W. H. Orem (2012), Tidally driven export of dissolved organic carbon, total mercury, and methylmercury from a mangrove-dominated estuary, Environ. Sci. Technol., 46(3), 1371-1378, doi:10.1021/ es2029137.

Bridgham, S. D., J. P. Megonigal, J. K. Keller, N. B. Bliss, and C. Trettin (2006), The carbon balance of North American wetlands, Wetlands, 26(4), 889-916, doi:10.1672/0277-5212(2006)26[889:TCBONA]2.0.CO;2.

Budishchev, A., Y. Mi, J. van Huissteden, L. Belelli-Marchesini, G. Schaepman-Strub, F. J. W. Parmentier, G. Fratini, A. Gallagher, T. C. Maximov, and J. J. Dolman (2014), Evaluation of a plot-scale methane emission model using eddy covariance observations and footprint modelling, Biogeosciences, 11(17), 4651-4664, doi:10.5194/bg-11-4651-2014.

Chmura, G. L., L. Kellman, and G. R. Guntenspergen (2011), The greenhouse gas flux and potential global warming feedbacks on a northern macrotidal and microtidal salt marsh, Environ. Res. Lett., 6(4), 044016, doi:10.1088/1748-9326/6/4/044016.

Christensen, S., et al. (1996), Nitrous oxide emission from an agricultural field: comparison between measurements by flux chamber and micrometeorological techniques, Atmos. Environ., 30(24), 4183-4190, doi:10.1016/1352-2310(96)00145-8.

Ciais, P., et al. (2013), Carbon and other biogeochemical cycles, in Climate Change 2013: The Physical Science Basis. Contribution of Working Group I to the Fifth Assessment Report of the Intergovernmental Panel on Climate Change, edited by T. F. Stocker et al., pp. 465-570, Cambridge Univ. Press, Cambridge, U. K., and New York.

Cropper, W. P., K. C. Ewel, and J. W. Raich (1985), The measurement of soil $\mathrm{CO}_{2}$ evolution in situ, Pedobiologia, 28(1), 35-40.

Crozier, C. R., and R. D. DeLaune (1996), Methane production by soils from different Louisiana marsh vegetation types, Wetlands, 16(2), 121-126, doi:10.1007/BF03160685.

DeLaune, R. D., C. J. Smith, and W. H. Patrick Jr. (1983), Methane release from Gulf coast wetlands, Tellus, 35B(1), 8-15, doi:10.1111/ j.1600-0889.1983.tb00002.x.

DeLaune, R. D., J. A. Nyman, and W. H. Patrick Jr. (1994), Peat collapse, ponding and wetland loss in a rapidly submerging coastal marsh, J. Coast. Res., 10(4), 1021-1030, doi:10.1007/978-1-4020-4271-3.

Edwards, N. T., and P. Sollins (1973), Continuous measurement of carbon dioxide evolution from partitioned forest floor components, Ecology, 54(2), 406-412, doi:10.2307/1934349.

Enwright, N. M., S. B. Hartley, B. R. Couvillion, M. G. Brasher, J. M. Visser, M. K. Mitchell, B. M. Ballard, M. W. Parr, and B. C. Wilson (2015), Delineation of marsh types from Corpus Christi Bay, Texas, to Perdido Bay, Alabama, in 2010: U.S. Geological Survey Scientific Investigations Map 3336, 1 sheet, scale 1:750,000, doi:10.3133/sim3336.

Foken, T., and B. Wichura (1996), Tools for quality assessment of surface-based flux measurements, Agric. For. Meteorol., 78(1-2), 83-105, doi:10.1016/0168-1923(95)02248-1.

Foken, T., M. Gockede, M. Mauder, L. Mahrt, B. D. Amiro, and J. W. Munger (2004), Post-field quality control, in Handbook of Micrometeorology: A Guide for Surface Flux Measurements, edited by X. Lee, W. J. Massman, and B. E. Law, pp. 81-108, Kluwer Acad., Dordrecht, Netherlands.

Forbrich, I., L. Kutzbach, C. Wille, T. Becker, J. Wu, and M. Wilmking (2011), Cross-evaluation of measurements of peatland methane emissions on microform and ecosystem scales using high-resolution landcover classification and source weight modelling, Agric. For. Meteorol., 151(7), 864-874, doi:10.1016/j.agrformet.2011.02.006.

Frolking, S., N. Roulet, and J. Fuglestvedt (2006), How northern peatlands influence the Earth's radiative budget: Sustained methane emissions versus sustained carbon sequestration, J. Geophys. Res., 111, G01008, doi:10.1029/2005JG000091.

Fuglestvedt, J. S., I. S. A. Isaksen, and W.-C. Wang (1996), Estimates of indirect global warming potentials for $\mathrm{CH}_{4}, \mathrm{CO}$ and $\mathrm{NO}_{x}, \mathrm{Clim}$. $\mathrm{Change}_{\text {, }}$ 34(3), 405-437, doi:10.1007/BF00139300.

Galvagno, M., et al. (2013), Phenology and carbon dioxide source/sink strength of a subalpine grassland in response to an exceptionally short snow season, Environ. Res. Lett., 8(2), 025008, doi:10.1088/1748-9326/8/2/025008.

Garnet, K. N., J. P. Megonigal, C. Litchfield, and G. E. Taylor Jr. (2005), Physiological control of leaf methane emission from wetland plants, Aquat. Bot., 81(2), 141-155, doi:10.1016/j.aquabot.2004.10.003.

Gauci, V., D. J. G. Gowing, E. R. C. Hornibrook, J. M. Davis, and N. B. Dise (2010), Woody stem methane emission in mature wetland alder trees, Atmos. Environ., 44(17), 2157-2160, doi:10.1016/j.atmosenv.2010.02.034.

Göckede, M., et al. (2008), Quality control of CarboEurope flux data-Part 1: Coupling footprint analyses with flux data quality assessment to evaluate sites in forest ecosystems, Biogeosciences, 5(2), 433-450, doi:10.5194/bg-5-433-2008.

Gorham, E. (1991), Northern peatlands: Role in the carbon cycle and probable responses to climatic warming, Ecol. Appl., 1(2), 182-195, doi:10.2307/1941811.

Gu, L., et al. (2005), Objective threshold determination for nighttime eddy flux filtering, Agric. For. Meteorol., 128(3-4), 179-197, doi:10.1016/ j.agrformet.2004.11.006.

Hanson, P. J., N. T. Edwards, C. T. Garten, and J. A. Andrews (2000), Separating root and soil microbial contributions to soil respiration: A review of methods and observations, Biogeochemistry, 48(1), 115-146, doi:10.1023/A:1006244819642. 
Hatala, J. A., M. Detto, O. Sonnentag, S. J. Deverel, J. Verfaillie, and D. D. Baldocchi (2012), Greenhouse gas $\left(\mathrm{CO}_{2}, \mathrm{CH}_{4}, \mathrm{H}_{2} \mathrm{O}\right)$ fluxes from drained and flooded agricultural peatlands in the Sacramento-San Joaquin Delta, Agric. Ecosyst. Environ., 150, 1-18, doi:10.1016/ j.agee.2012.01.009.

Holm, G. O., Jr, B. C. Perez, D. E. McWhorter, K. W. Krauss, D. J. Johnson, R. C. Raynie, and C. J. Killebrew (2016), Ecosystem level methane fluxes from tidal freshwater and brackish marshes of the Mississippi River Delta: Implications for coastal wetland carbon projects, Wetlands, doi:10.1007/s13157-016-0746-7, in press.

Ibrom, A., E. Dellwik, H. Flyvbjerg, N. O. Jensen, and K. Pilegaard (2007), Strong low-pass filtering effects on water vapor flux measurements with closed-path eddy correlation systems, Agric. For. Meteorol., 147(3-4), 140-156, doi:10.1016/j.agrformet.2007.07.007.

Kathilankal, J. C., T. J. Mozdner, J. D. Fuentes, P. D'Odorico, K. J. McGlathery, and J. C. Zieman (2008), Tidal influences on carbon assimilation by a salt marsh, Environ. Res. Lett., 3, 044010, doi:10.1088/1748-9326/3/4/044010.

Kljun, N., P. Calanca, M. Rotach, and H. Schmid (2004), A simple parameterization for flux footprint predictions, Bound. Layer Meteorol., 112(3), 503-523, doi:10.1023/B:BOUN.0000030653.71031.96.

Knoepp, J. D., and J. M. Vose (2002), Quantitative Comparison of In Situ Soil $\mathrm{CO}_{2}$ Flux Measurement Methods, Research Paper SRS-28, USDA Forest Service, Asheville, N. C.

Knox, S. H., C. Sturtevant, J. H. Matthes, L. Koteen, J. Verfaillie, and D. Baldocchi (2014), Agricultural peatland restoration: Effects of land-use change on greenhouse gas $\left(\mathrm{CO}_{2}\right.$ and $\left.\mathrm{CH}_{4}\right)$ fluxes in the Sacramento-San Joaquin Delta, Global Change Biol., 21(2), 750-765, doi:10.1111/ gcb.12745.

Kormann, R., and F. X. Meixner (2001), An analytical footprint model for nonneutral stratification, Bound. Layer Meteorol., 99(2), 207-224, doi:10.1023/A:1018991015119.

Kosters, E. C., G. L. Chmura, and A. Bailey (1987), Sedimentary and botanical factors influencing peat accumulation in the Mississippi Delta J. Geol. Soc. Lond., 144(3), 423-434, doi:10.1144/gsjgs.144.3.0423.

Krauss, K. W., and J. L. Whitbeck (2012), Soil greenhouse gas fluxes during wetland forest retreat along the lower Savannah River, Georgia (USA), Wetlands, 32(1), 73-81, doi:10.1007/s13157-011-0246-8.

Li-Cor Biosciences (2012), EddyPro 4.0: Help and user's guide, 208 pp., Lincoln, Nebraska.

Livingston, G. P., and G. L. Hutchinson (1995), Enclosure-based measurement of trace gas exchange: Applications and sources of errors, in Biogenic Trace Gases: Measuring Emissions From Soil and Water, edited by P. A. Matson and R. C. Harriss, pp. 14-51, Blackwell Publ., Oxford.

Magenheimer, J. F., T. R. Moore, G. L. Chmura, and R. J. Daoust (1996), Methane and carbon dioxide flux from a macrotidal salt marsh, Bay of Fundy, New Brunswick, Estuaries, 19(1), 139-145, doi:10.2307/1352658.

Mauder, M., and T. Foken (2006), Impact of post-field data processing on eddy covariance flux estimates and energy balance closure, Meteorol. Z., 15(6), 597-609, doi:10.1127/0941-2948/2006/0167.

Megonigal, J. P., and W. H. Schlesinger (1997), Enhanced $\mathrm{CH}_{4}$ emissions from a wetland soil exposed to elevated $\mathrm{CO}_{2}$, Biogeochemistry, $37(1)$, 77-88, doi:10.1023/A:1005738102545.

Megonigal, J. P., and W. H. Schlesinger (2002), Methane-limited methanotrophy in tidal fresh swamps, Global Biogeochem. Cycles, 16(4), 1088, doi:10.1029/2001GB001594.

Meijide, A., G. Manca, I. Goded, V. Magliulo, P. di Tommasi, G. Seufert, and A. Cescatti (2011), Seasonal trends and environmental controls of methane emissions in a rice paddy field in Northern Italy, Biogeosciences, 8(12), 3809-3821, doi:10.5194/bg-8-3809-2011.

Miller, W. D., S. C. Neubauer, and I. C. Anderson (2001), Effects of sea level induced disturbances on high salt marsh metabolism, Estuaries, 24(3), 357-367, doi:10.2307/1353238.

Mitsch, W. J., B. Bernal, A. M. Nahlik, Ü. Mander, L. Zhang, C. J. Anderson, S. E. Jørgensen, and H. Brix (2013), Wetlands, carbon, and climate change, Landscape Ecol., 28(4), 583-597, doi:10.1007/s10980-012-9758-8.

Moffett, K. B., A. Wolf, J. A. Berry, and S. M. Gorlick (2010), Salt marsh-atmosphere exchange of energy, water vapor, and carbon dioxide: Effects of tidal flooding and biophysical controls, Water Resour. Res., 46, W10525, doi:10.1029/2009WR009041.

Moncrieff, J. B., J. M. Massheder, H. de Bruin, J. Ebers, T. Friborg, B. Heusinkveld, P. Kabat, S. Scott, H. Soegaard, and A. Verhoef (1997), A system to measure surface fluxes of momentum, sensible heat, water vapour and carbon dioxide, J. Hydrol., 188-189, 589-611, doi:10.1016/ S0022-1694(96)03194-0.

Moncrieff, J. B., R. Clement, J. Finnigan, and T. Meyers (2004), Averaging, detrending and filtering of eddy covariance time series, in Handbook of Micrometeorology: A Guide for Surface Flux Measurements, edited by X. Lee, W. J. Massman, and B. E. Law, pp. 7-31, Kluwer Acad., Dordrecht, Netherlands.

Moseman-Valtierra, S., R. Gonzalez, K. D. Kroeger, J. Tang, W. C. Chao, J. Crusius, J. Bratton, A. Green, and J. Shelton (2011), Short-term nitrogen additions can shift a coastal wetland from a sink to a source of $\mathrm{N}_{2} \mathrm{O}$, Atmos. Environ., 45(26), 4390-4397, doi:10.1016/j. atmosenv.2011.05.046.

Myhre, G., et al. (2013), Anthropogenic and natural radiative forcing, in Climate Change 2013: The Physical Science Basis, edited by T. F. Stocker et al., pp. 659-740, Cambridge Univ. Press, Cambridge, U. K., and New York.

Neubauer, S. C. (2008), Contributions of mineral and organic components to tidal freshwater marsh accretion, Estuarine Coastal Shelf Sci., 78(1), 78-88, doi:10.1016/j.ecss.2007.11.011.

Neubauer, S. C. (2013), Ecosystem responses of a tidal freshwater marsh experiencing saltwater intrusion and altered hydrology, Estuaries Coasts, 36(3), 491-507, doi:10.1007/s12237-011-9455-x.

Neubauer, S. C. (2014), On the challenges of modeling the net radiative forcing of wetlands: Reconsidering Mitsch et al. (2013), Landscape Ecol., 29(4), 571-577, doi:10.1007/s10980-014-9986-1.

Neubauer, S. C., and J. P. Megonigal (2015), Moving beyond global warming potentials to quantify the climatic role of ecosystems, Ecosystems, 18(6), 1000-1013, doi:10.1007/s10021-015-9878-4.

Neubauer, S. C., M. D. Miller, and I. C. Anderson (2000), Carbon cycling in a tidal freshwater marsh ecosystem: A carbon gas flux study, Mar Ecol. Prog. Ser., 199, 13-30, doi:10.3354/meps199013.

Norman, J. M., C. J. Kuckarik, S. T. Gower, D. D. Baldocchi, P. M. Crill, M. Rayment, K. Savage, and R. G. Striegl (1997), A comparison of six methods for measuring soil-surface carbon dioxide fluxes, J. Geophys. Res., 102(D24), 28,771-28,777, doi:10.1029/97JD01440.

Nyman, J. A., and R. D. DeLaune (1991), $\mathrm{CO}_{2}$ emission and soil Eh responses to different hydrological conditions in fresh, brackish, and saline marsh soils, Limnol. Oceanogr., 36(7), 1406-1414, doi:10.4319/lo.1991.36.7.1406.

Olsson, L., S. Ye, X. Yu, M. Wei, K. W. Krauss, and H. Brix (2015), Factors influencing $\mathrm{CO}_{2}$ and $\mathrm{CH}_{4}$ emissions from coastal wetlands in the Liaohe Delta, Northeast China, Biogeosciences, 12(16), 4965-4977, doi:10.5194/bg-112-4965-2015.

Pangala, S. R., S. Moore, E. R. C. Hornibrook, and V. Gauci (2013), Trees are major conduits for methane egress from tropical forested wetlands, New Phytol., 197(2), 524-531, doi:10.1111/nph.12031. 
Papale, D., et al. (2006), Towards a standardized processing of net ecosystem exchange measured with eddy covariance technique: Algorithms and uncertainty estimation, Biogeosciences, 3(4), 571-583, doi:10.5194/bg-3-571-2006.

Petrescu, A. M. R., et al. (2015), The uncertain climate footprint of wetlands under human pressure, Proc. Natl. Acad. Sci. U.S.A., 112(15), 4594-4599, doi:10.1073/pnas.1416267112.

Poffenbarger, H. J., B. A. Needelman, and J. P. Megonigal (2011), Salinity influence on methane emissions from tidal marshes, Wetlands, 31(5), 831-842, doi:10.1007/s13157-011-0197-0.

Raich, J. W., and W. H. Schlesinger (1992), The global carbon dioxide flux in soil respiration and its relationship to vegetation and climate, Tellus B, 44(2), 81-99, doi:10.1034/j.1600-0889.1992.t01-1-00001.x.

Raich, J. W., R. D. Bowden, and P. A. Steudler (1990), Comparison of two static chamber techniques for determining carbon dioxide efflux from forest soils, Soil Sci. Soc. Am. J., 54(6), 1754-1757, doi:10.2136/sssaj1990.03615995005400060041x.

Reichstein, M., et al. (2005), On the separation of net ecosystem exchange into assimilation and ecosystem respiration: Review and improved algorithm, Global Change Biol., 11(9), 1424-1439, doi:10.1111/j.1365-2486.2005.001002.x.

Rocha, A. V., and M. L. Goulden (2009), Why is marsh productivity so high? New insights from eddy covariance and biomass measurements in a Typha marsh, Agric. For. Meteorol., 149(1), 159-168, doi:10.1016/j.agrformet.2008.07.010.

Rochette, P., E. G. Gregorich, and R. L. Desjardins (1992), Comparison of static and dynamic closed chambers for measurement of soil respiration under field conditions, Can. J. Soil Sci., 72(4), 605-609, doi:10.4141/cjss92-050.

Rochette, P., B. Ellert, E. G. Gregorich, R. L. Desjardins, E. Pattey, R. Lessard, and B. G. Johnson (1997), Description of a dynamic closed chamber for measuring soil respiration and its comparison with other techniques, Can. J. Soil Sci., 77(2), 195-203, doi:10.4141/S96-110.

Sasser, C. E., J. G. Gosselink, E. M. Swenson, C. M. Swarzenski, and N. C. Leibowitz (1996), Vegetation, substrate, and hydrology in floating marshes in the Mississippi river delta plain wetlands, USA, Vegetatio, 122(2), 129-142, doi:10.1007/BF00044695.

Schäfer, K. V. R., R. Tripathee, F. Artigas, T. H. Morin, and G. Bohrer (2014), Carbon dioxide fluxes of an urban tidal marsh in the Hudson-Raritan estuary, J. Geophys. Res. Biogeosci., 119, 2065-2081, doi:10.1002/2014JG002703.

Schlesinger, W. H., and J. A. Andrews (2000), Soil respiration and the global carbon cycle, Biogeochemistry, 48(1), 7-20, doi:10.1023/ A:1006247623877.

Shoemaker, W. B., F. Anderson, J. G. Barr, S. L. Graham, and D. B. Botkin (2015), Carbon exchange between the atmosphere and subtropical forested cypress and pine wetlands, Biogeosciences, 12(8), 2285-2300, doi:10.5194/bg-12-2285-2015.

Snedden, G. A., K. F. Cretini, and B. Patton (2015), Inundation and salinity impacts to above- and belowground productivity in Spartina patens and Spartina alterniflora in the Mississippi River deltaic plain: Implications for using river diversions as restoration tools, Ecol. Eng., 81, 133-139, doi:10.1016/j.ecoleng.2015.04.035.

Swarzenski, C. M., E. M. Swenson, C. E. Sasser, and J. G. Gosselink (1991), Marsh mat floatation in the Louisiana delta plain, J. Ecol., 79(4), 999-1011, doi:10.2307/2261094.

Teh, Y. A., W. L. Silver, O. Sonnentag, M. Detto, M. Kelly, and D. D. Baldocchi (2011), Large greenhouse gas emissions from a temperate peatland pasture, Ecosystems, 14(2), 311-325, doi:10.1007/s10021-011-9411-4.

U.S. Climate Data (2016), For Houma, Louisiana. [Available at http://www.usclimatedata.com/climate/houma/louisiana/united-states/ usla0224, accessed 17 February 2016.]

Vann, C. D., and J. P. Megonigal (2003), Elevated $\mathrm{CO}_{2}$ and water depth regulation of methane emissions: Comparison of woody and nonwoody wetland plant species, Biogeochemistry, 63(2), 117-134, doi:10.1023/A:1023397032331.

Vickers, D., and L. Mahrt (1997), Quality control of flux sampling problems for tower and aircraft data, J. Atmos. Oceanic Technol., 14(3), 512-526, doi:10.1175/1520-0426(1997)014<0512:QCAFSP>2.0.CO;2.

Webb, E. K., G. I. Pearman, and R. Leuning (1980), Correction of the flux measurements for density effects due to heat and water vapor transfer, Q. J. R. Meteorol. Soc., 106(447), 85-100, doi:10.1002/qj.49710644707.

Weston, N. B., R. E. Dixon, and S. B. Joye (2006), Ramifications of increased salinity in tidal fresh sediments: Geochemistry and microbial pathways of organic matter mineralization, J. Geophys. Res., 111, G01009, doi:10.1029/2005JG000071.

Weston, N. B., M. A. Vile, S. C. Neubauer, and D. J. Velinsky (2011), Accelerated microbial organic matter mineralization following salt-water intrusion into tidal fresh marsh soils, Biogeochemistry, 102(1-3), 135-151, doi:10.1007/s10533-010-9427-4.

Weston, N. B., S. C. Neubauer, D. J. Velinsky, and M. A. Vile (2014), Net ecosystem carbon exchange and the greenhouse gas balance of tidal marshes along an estuarine salinity gradient, Biogeochemistry, 120(1), 163-189, doi:10.1007/s10533-014-9989-7.

Whalen, S. C. (2005), Biogeochemistry of methane exchange between natural wetlands and the atmosphere, Environ. Eng. Sci., 22(1), 73-94, doi:10.1089/ees.2005.22.73.

Whiting, G. J., and J. P. Chanton (1993), Primary production control of methane emission from wetlands, Nature, 364, 794-795, doi:10.1038/ $364794 a 0$.

Wigand, C., et al. (2014), Below the disappearing marshes of an urban estuary: Historic nitrogen trends and soil structure, Ecol. Appl., 24(4), 633-649, doi:10.1890/13-0594.1.

Wilson, B. J., B. Mortazavi, and R. P. Kiene (2015), Spatial and temporal variability in carbon dioxide and methane exchange at three coastal marshes along a salinity gradient in a northern Gulf of Mexico estuary, Biogeochemistry, 123(3), 329-347, doi:10.1007/s10533-015-0085-4

Wolf, S., W. Eugster, C. Potvin, B. L. Turner, and N. Buchmann (2011), Carbon sequestration potential of tropical pasture compared with afforestation in Panama, Global Change Biol., 17(9), 2763-2780, doi:10.1111/j.1365-2486.2011.02460.x.

Yu, K., S. P. Faulkner, and M. J. Baldwin (2008), Effect of hydrological conditions on nitrous oxide, methane, and carbon dioxide dynamics in a bottomland hardwood forest and its implications for soil carbon sequestration, Global Change Biol., 14(4), 798-812, doi:10.1111/j.13652486.2008.01545.x. 